\title{
ملغم البهث
}

هذا البحث يدرس دلالة اختلاف التعبير بـــ (ختم و طبع) فـي القر آن الكريم من خلال شو اهدهما، ويناقش ما قيل فيهمـــا مــن أنهما بمعنى و احد، أو أن الثاني أقوى من الأول، و أنهما من باب المجاز أو الحقيقة، وكيف كانت شو اهد (طبع) أكثر من شـــو اهد (ختم)، وما في كل منهما من خصوصيات حيث اختصت (ختم) بالقلوب، و الأسماع، و الأفو اه، وجاءت (طبع) مرة و احدة علـىى القلوب، و الأسماع، و الأبصار ، وما عدا ذللك كانت على القلوب فقط إلا أن شو اهدها - غالبا - تختم بنفي السمع، أو العلـــ، أو الفقه، أو الإيمان، ولكل شـــاهد مقامــهـ الــذي يجليـــه مـــوطن الاستد لال، ودار البحث حول ذلك در اسة ومناقشة.

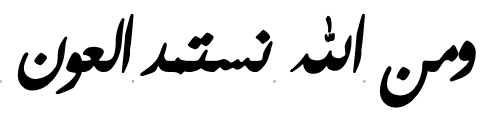




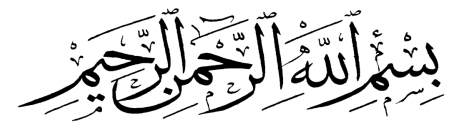

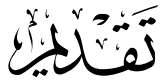

\section{الحمد لله وسلام على عباده الذين اصطفى.}

\section{وبعد،6666، 6}

فهذه در اسة موجزة تبحث المدلول البلاغي لكلمنين من كلام رب العـزة تبارك اسمه - تداخل مفهومهما في كلام اللغويين و المفسرين فر أوا أن إحـــداهما بمعنى الأخرى، أو كأن إحداهما الأخرى، ومن فرّق بينهما لم يذكر كبير معنى، لبه مع أن لكل كلمة في بيان الله دلالة، وذاك ما قصدت إليه در اسة مادنيهما: (ختم) و (طبع)، وردت الأولى خمس مرات في القرآن مسلطة على القلب و الـسمع بصرف النظر عن الإفر اد والجمع - في آيتين، و على القلب وحده فــي آيتـين، و على الأفو اه في آية واحدة، وجاءت الثانية (طبع) أحد عشرة مرة، مسلطة على

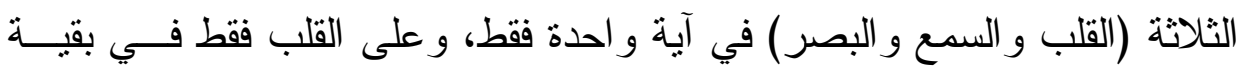

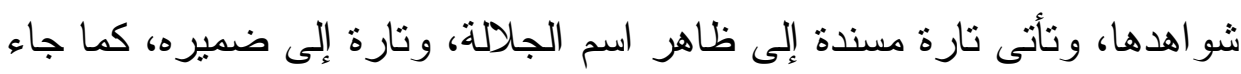

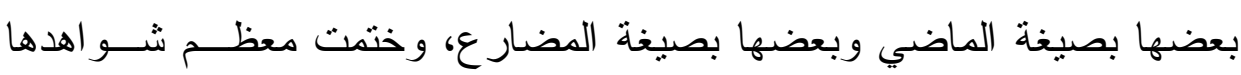
بنفي الإيمان، أو السمع، أو الفقه، أو العلم، ولكل شـاهد دلالة في ســياقه، وبــين مقامه وسبب نزوله، و الدلالة البلاغية تُستمد من كل ذلإنك.

ومن ثم قام أساس البحث على: مقدمة، وتمهيد، وثثلاثة مباحث، وخاتمــة، ودليل لموضوعاته، وثبث لمصادره ومراجعه، فالتمهيد يبحث مسألتين: الأولى: المعنى اللغوي للمادتين وما بينهما من نشابك. والثانية: تصنيفهما في القرآن الكريم. 
والمبحث المأول: استعمال (ختم و طبع) على القلوب و الأسماع، مع در اسة

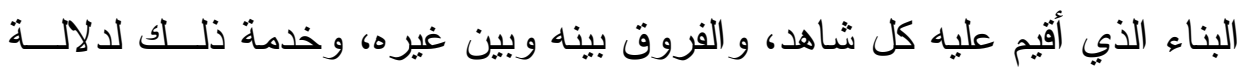

والمبحث الثـاني: استعمال (ختم) على القـــوب و اخت صـاصها بــالأفو اه،

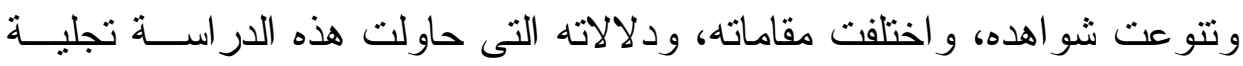

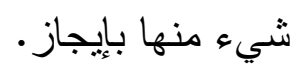

والمبحث الثالث: استعمال (طبع) على القلوب وحدها، و اعتمدت الدراسة

في كل ذلك على التحليل و التعليل و المناقثنة.

والن م. وله القصس وهو نعم المول ونع الثصم

الأستاذ الدكتور

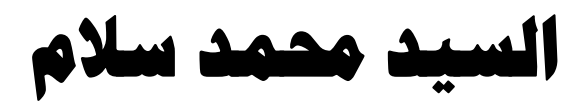

أستاذ البلاغة والنقد ووكيل الكلية 


\section{$\int_{0.00}^{2}$ \\ ا- المعاني اللغوية لمادتي (ختم وطبع)}

هناك تداخل كبير بين معنى المادتين لدرجة أن العلماء يجعلون الختم طبعا، و الطبع ختما. لذلك لا أسرد هنا كلامهم في معنى (ختم) ثم كلامهم فــي معنـى ئى (طبع) إنما أسوق هذه المعانى من خلال المادتين معا، حتـى تتجلــى الفــروق الدقيقة بينهما فتكون مر آة في طليعة هذه الدر اسة الموجزة ترشد إلى شيء مــن مـن

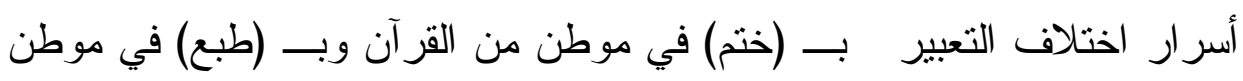
آخر ، وبغير هما في ثالث.... و هكذا.

ففي معنى (ختم) يقول ابن فارس: الخاء و التاء و الميم أصل و احـد، وهـــ

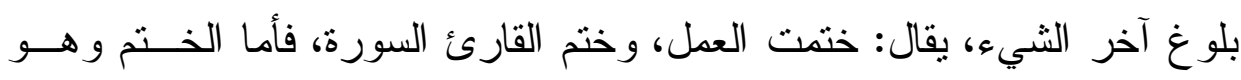
الطبع على الثيء فذلك من الباب أيضا، لأن الطبع على الثيء لا يكون إلا بعد إلى

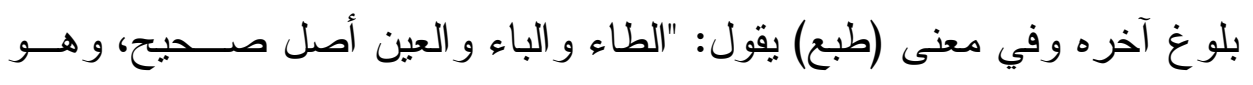

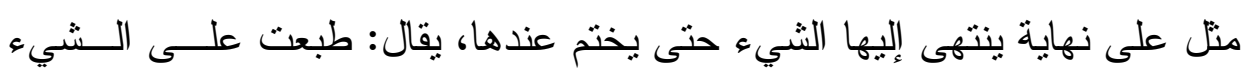

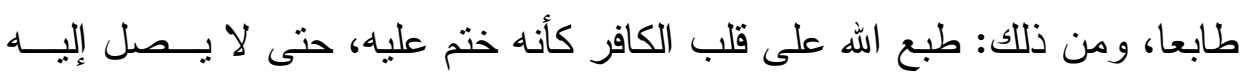
هدى ولا نور فلا يوفق لخير" (')

فنلحظ التقارب الثديد في عرضه معنى المادتين حتى قال في الأولى: فأمســا الختم وهو الطبع..، وقال في الثانية: طبع الله على قلب الكافر كأنه ختم عليــه،

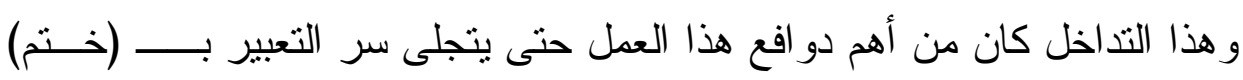
هنا، و (طبع) هناك.

(1) مقاييس اللغة (ختم) و (طبع). 
أما الر اغب الأصفهاني فدرسهما كأنهما شيء و احد وهو يتحدث عن معنـى (ختم) ثم فرق بينهما من جهة العموم و الخصوص وهو يتحدث عن معنى (طبع)

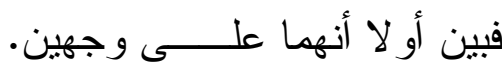

الأول: مصدر ختمت وطبعت، وهو تأثنر الثيء كنقش الخاتم و الطابع. والثانى: الأثر الحاصل عن النقش، ويتجوز بذلك تارة في الاستيناق من الثيء و المنع منه، اعتبار ا بما يحصل من المنع بالختم على الكتب و الأبو اب، نحو "ختم الله على قلوبهر"، "ختم الله على سمعه وقلبه". ووضح ذلك بأنه إثنارة إلى ما أجرى الله به العادة أن الإنسان إذا تتاهى في اعتقاد باطل أو ارتكاب محظور و لا يكون منه تلفت بوجه إلى الحق، يورثه ذلك

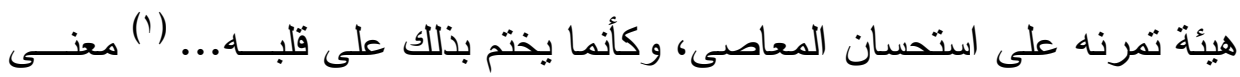

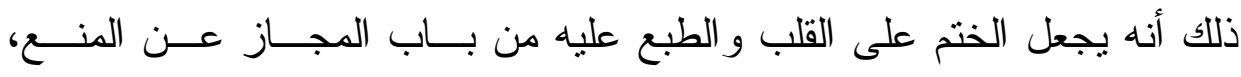

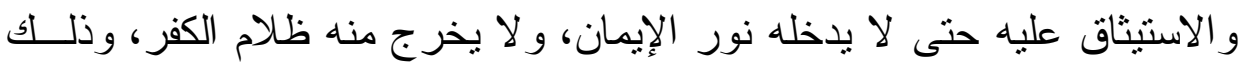
عقابا له، ويؤكد هذه الوجهة قوله بعدها: وعلى هذا النحو استعارة الإغفال فـي

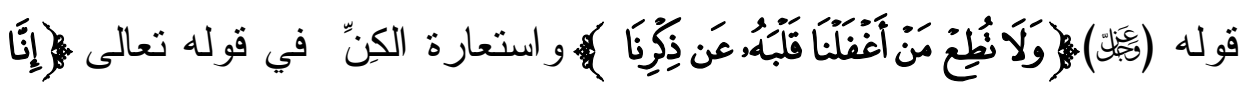

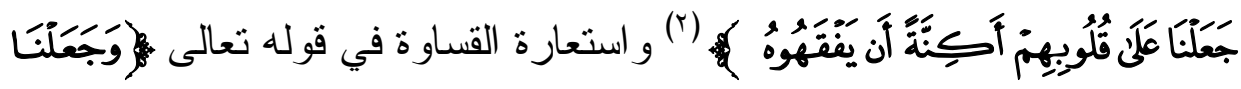

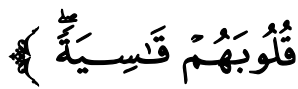

\section{وسيأتى - خلال الدراسة - مناقشة ذلك إن شاء الله.}

أما في حديثه عن معنى (طبع) فقال:" الطبع: أن تصور الثيء بصورة مّــا كطبع السكة وطبع الدرهم، وهو أعم من الختم، و أخص من النقش وبين ما فـي إني

$$
\begin{aligned}
& \text { (1) المفردات في غريب القرآن (ختم) و (طبح). }
\end{aligned}
$$

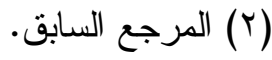


معنى (طبع) من السجية، أى نقش النفس بصورة مّا، إما من حيث الخلقه، وإمــا

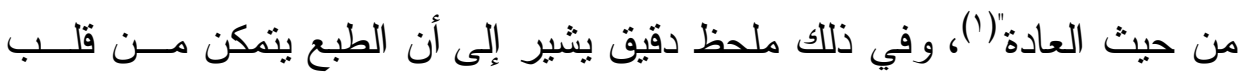

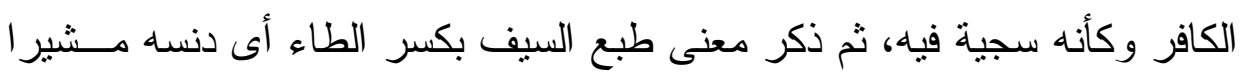

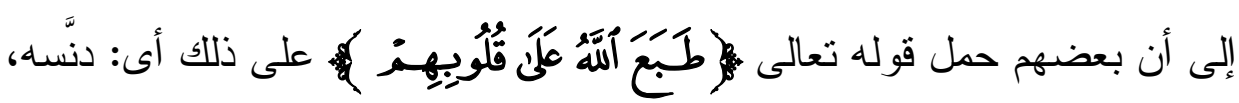

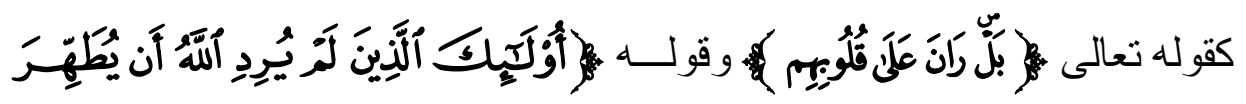

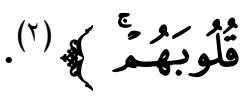

أطلت الأخذ من الر اغب لما في بيانه من دقائق رجـع إليهـــــــــــر مـن العلماء، وسنحتاج إليها في دراسة أسر ار التعبير وفروقه.

وجعل ابن منظور الختم بمعنى الطبع، فقال: ختمه يختمه ختـــا طبعـهـ..

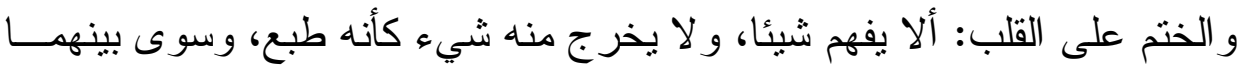

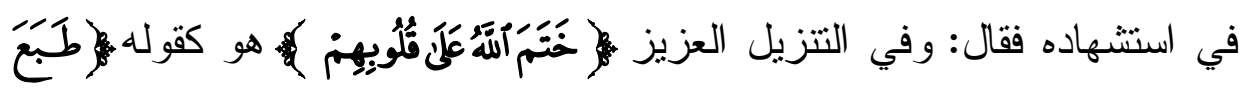

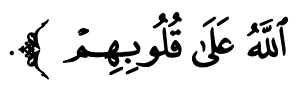

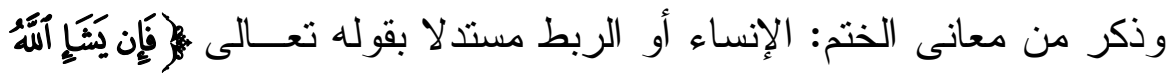

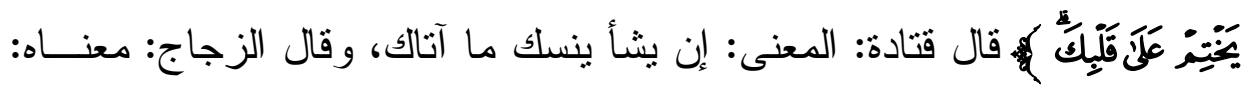

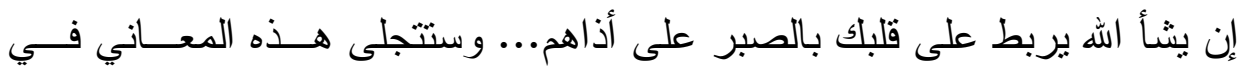
در اسة هذا الثناهد.

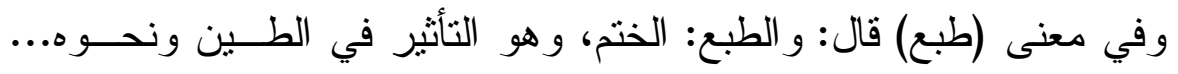

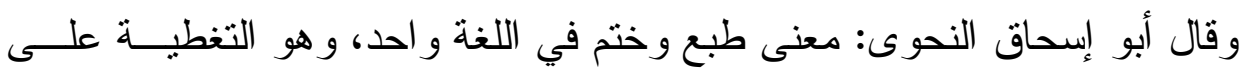

$$
\begin{aligned}
& \text { (1) المرجع السابق. } \\
& \text { (r) المرجع السابق. }
\end{aligned}
$$




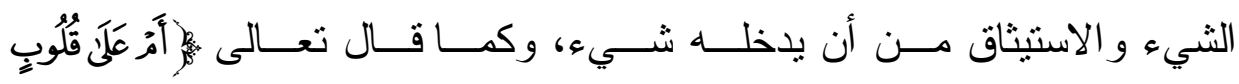

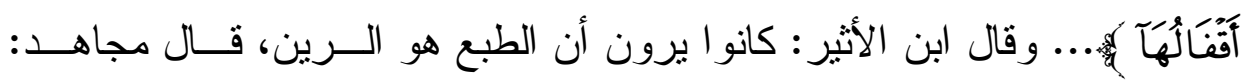
الرين أيسر من الطبع، والطبع أيسر من الإقفال، والإقفال أثند من ذلك كله. هذا تفسير الطبع. (')

و هكذا تو ارد أصحاب المعاجم على هذه المعانى ودارو ا حولها وتتاقلوها.

ولكن أبا هلال العسكرى رأى أن الطبع أثند من الختم، وكأن الختم مرحلـــة

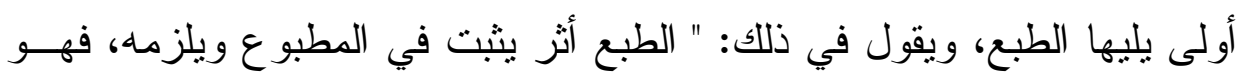
يفيد من معنى الثبات و اللزوم ما لا يفيده الختم، ولهذا قيل: طبع الــدر هم طبعـــا. وهو الأثر الذي يؤثزه فلا يزول عنه، كذللك أيضا قيل: طبع الإنسان، لأنه ثابــــ غير زائل، وقيل: طبع فلان على هذا الخلق إذا كــان لا بــزورل عنــهـ. وقـــال

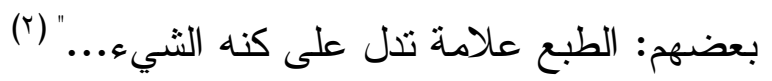

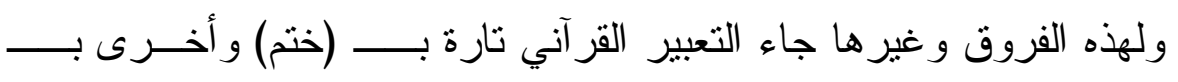

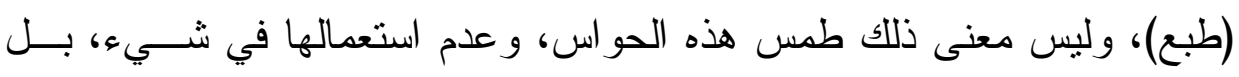

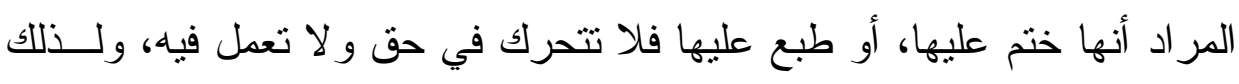
يقول الأزهري: " فمعنى (ختم) طبع الله على قلوبهم بكفرهم، وهم كانو ا يسمعون

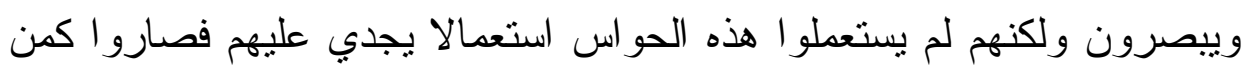

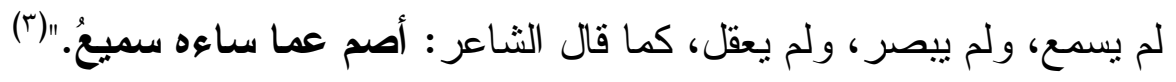

$$
\text { ( (1) ينظر لسان العرب (ختم) و (طبع). }
$$

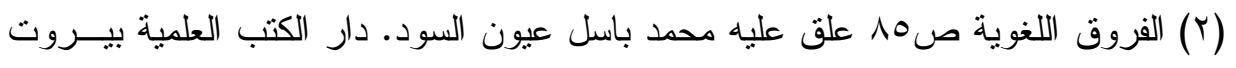

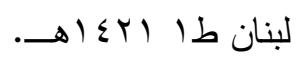

(r) (r) تهذيب اللغة (ختم) 
و أفاد من ذلك بعض العلماء وبينو ا أن المعنى في (ختم): منع نفوذ الحــق علــى القلب، فالتعبير بالختم يصور القلب بيتا بناه الله تعالى ليكون خزينة الجو اهر، ثم

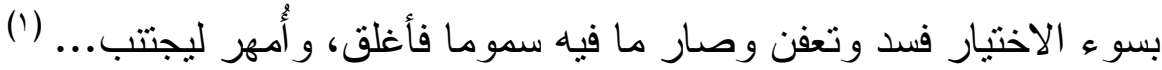
وتأتى ختم بمعنى (منع) وسيأتي ذلك في سياق كل شاهد من شو اهد (خـتم) و (طبع) وستتجلى خصائص التعبير بكل مادة منهما دون الأخرى. إن شاء الله.

\section{r - استعمال المادتين في القرآن الكريم:}

جاءت (ختم) في القر آن الكريم في خمسة شو اهد، ثلاثة منها بصيغة الماضــى، و الثين بصيغة المضارع، وتوجهت الصيغة الأولى إلى القلوب أولا ثم الأســماع مرة، و إلى الأسماع ثم القلوب ثانية، و إلى القلوب وحدها ثالثنة غير أنها في هــــه

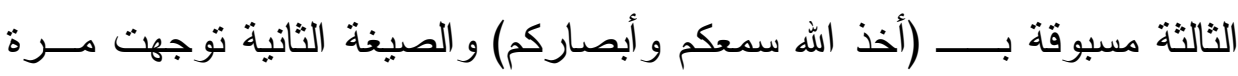

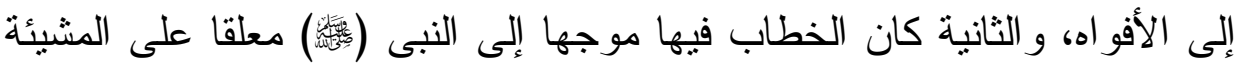

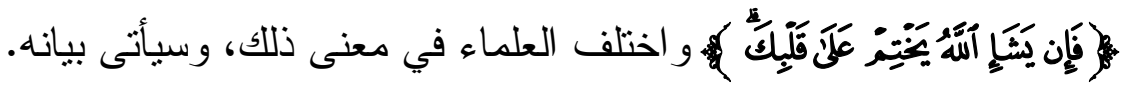
أما (طبع) فجاءت في أحد عثر شاهدا، ستة منها بصيغة الماضي، أربعــة بالبناء للمعلوم ومسنده إلى اسم الجالالة، و اثتين بالبناء للمفعول، وكلهــــا موجهـــة إلى القلوب إلا و احدة فناملة للقلوب و الأسماع، وختم بعضها بنفي الإيمان عنهم، وبعضها بنفي العلم، وبعضها بنفي الفقه، وبعضها عطف عليها ا تباع الأهـــواء، أما التي شملت الثثلاثة (القلوب و الأسماع و الأبصار) فكانت نهايتها إثبات الغفلـــة

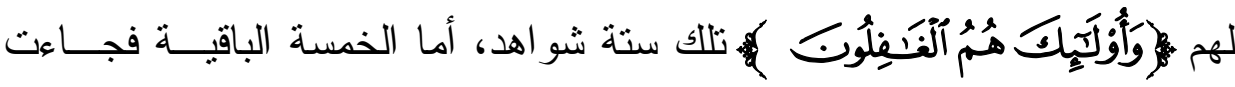
بصيغة المضار ع ثناثة منها مسندة إلى صريح اسم الجلالة، و انثين إلى ضميره،

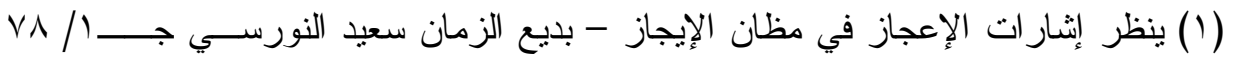
تحقيق إحسان قاسم الصالحي. 
ومصاغة بضمير العظمة (نطبع) وكلها موجهة إلى القلوب، إما قلوب الكافرين، و إما قلوب المعتدين كما وسمهم القرآن، و إما قلوب الذين لا يعلمون، و إما قلوب

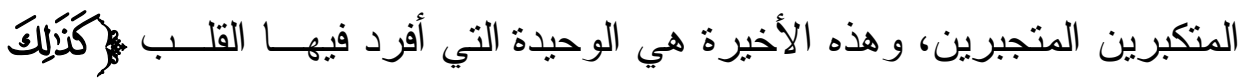

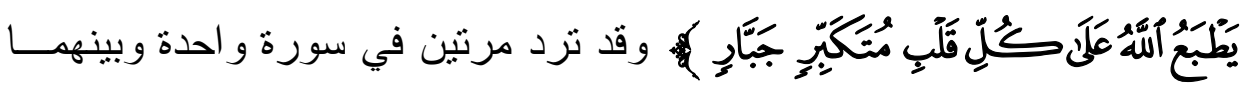

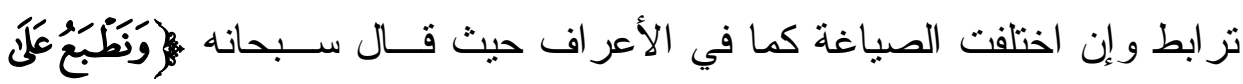

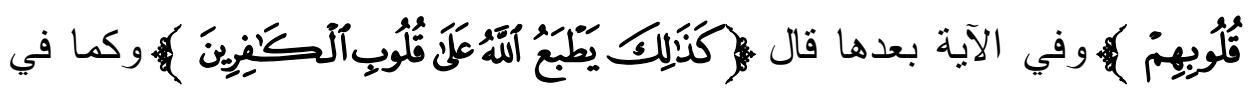

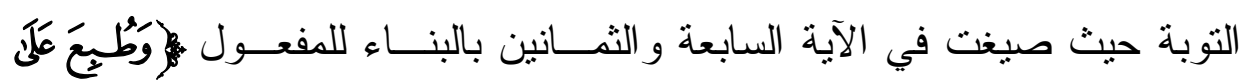

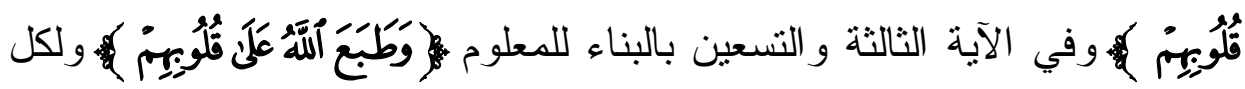
سياق دلالته ودو اعيه التي نتاسب مقامه. 


\section{المبحدث الأول \\ راستعمال (ختم) و (طبع) على القلوب والأسماعا}

جاءت (ختم) على القلوب و الأسماع بصيغة الجمع في القلوب، و الإفر اد في

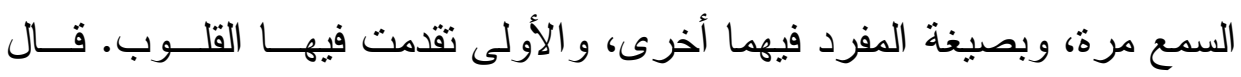

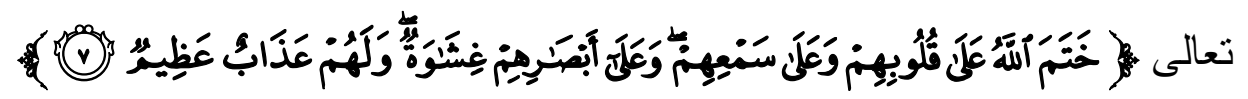

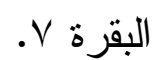

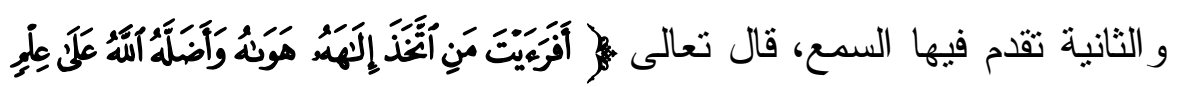

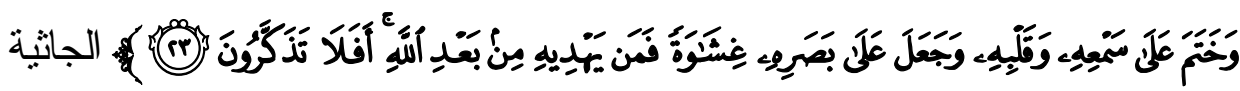
سب وبينهما فروق سنبينها الدر اسة.

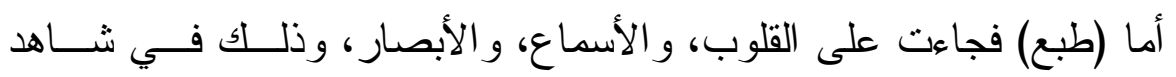
و احد.

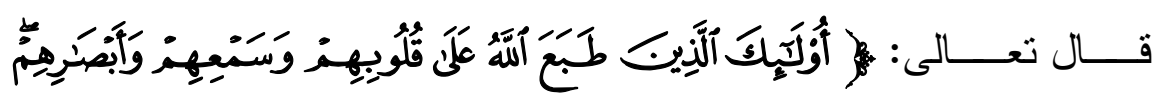

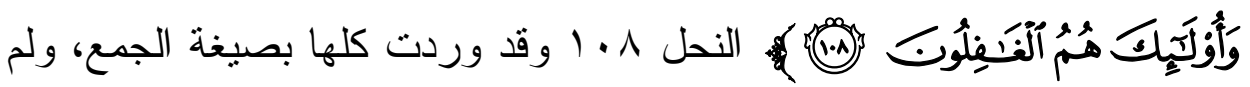
يأت على الأبصار ختم، بل جاءت عليها الغشاوة، ولم يأت عليها طبــع إلا فــي

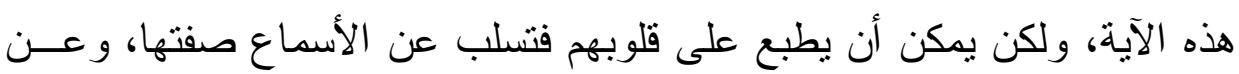

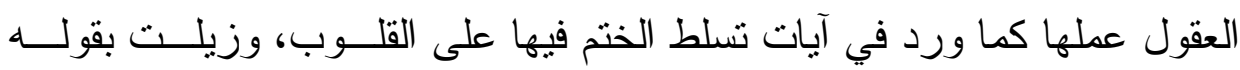

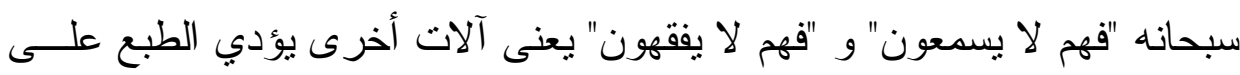
القلوب إلى تعطيلها عن سماع الحق وفقهه..

و الملاحظ هنا أن (طبع) فيها عموم ليس في ختم حيث تسلطت على الثلاثة (القلب و السمع و البصر ) و أدت إلى تعطيل السمع تارة و الفقه أخرى. 
وتثور الدر اسة الآن حول الفرق بين (ختم) مسلطة على القالــوب و الـسمع فقط، و اختصاص البصر بالغشاوة، و (طبع) مسلطة على الثلاثة وذلك في آيتـي البقرة و النحل السابقتني، مع اثتنر اكهما في إفر اد السمع. وفي الآيتنين دلالة على أن الطبع أثند من الختم، وفيه من التبات و اللزوم ما ليس في الختم كما سبق في تفريق أبي هلا العسكري بينهما، وفي قــول ابــن

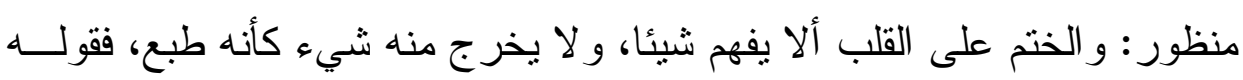
(كأنه طبع) يفيد أصولية الطبع وثباته وكأن الختم شبيه به، و الطبع هـــو آخــر

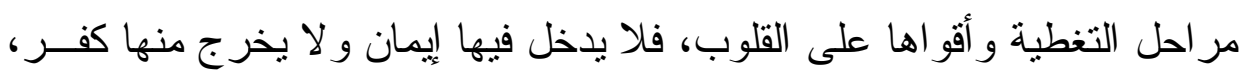
و لا برجى لها برء.

وبالنظر في الآينتين: آية البقرة، وآية النحل نجد أنهما في ســـاق الحــديث عن الكافرين حيث جاءت آية البقرة تعليلا لاستو اء الإنذار و عدمه عنــدهم فـي بــي

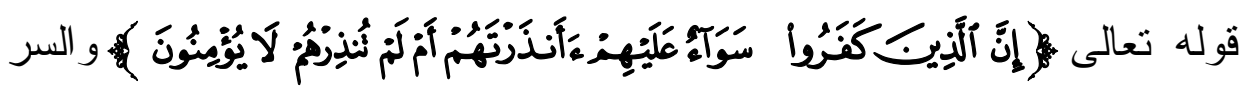
في ذلك هو ذلك الختم على قلوبهم، و الذي صـار إليهح بإنكار هم وسوء صـــنيعهم،

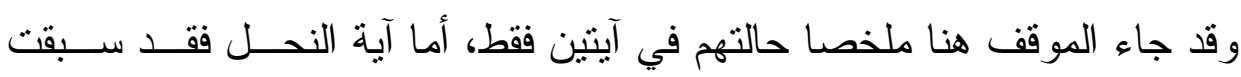

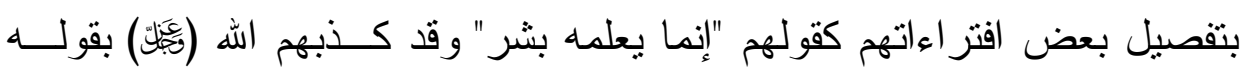

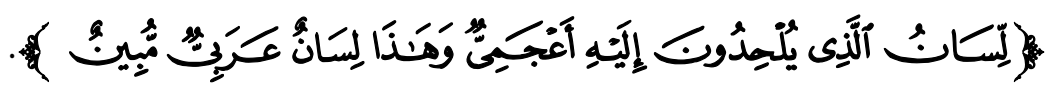
قيل: كان غلامان نصر انيان يقر آن كتابا لهم بلسانهم، وكان رسول الله (؛ يمر بهما فيسمع قر اعتهما، وكان المشركون يقولون: يتعلم منهما فأكذبهم الله بهذه

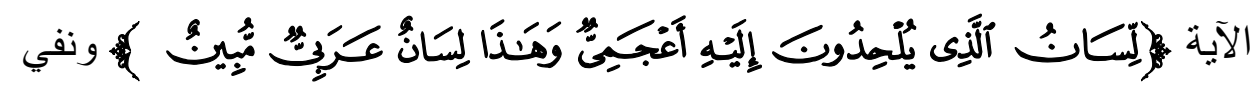

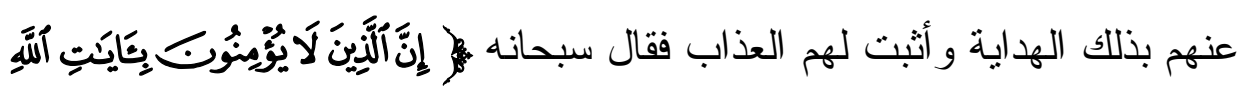

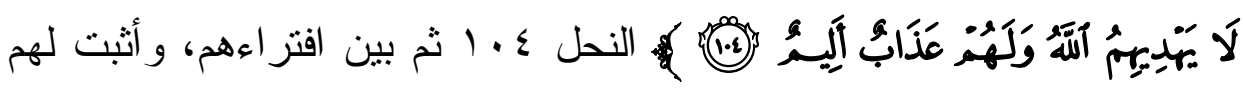




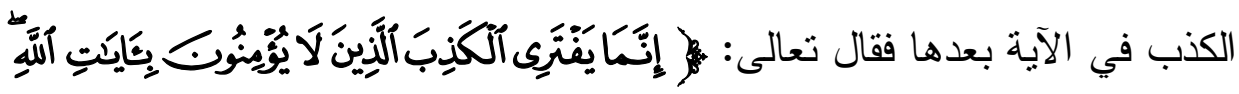

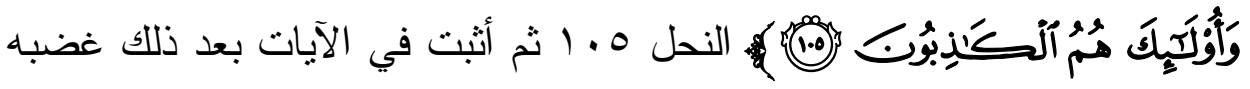
عليهم، وبين استحبابهم الحياة الدنيا على الآخرة، ثم جاء هذا الحكم القاطع الجامع بالطبع على القلوب و السمع، و الأبصار، ثم التذييل القاطع بغفلتهم

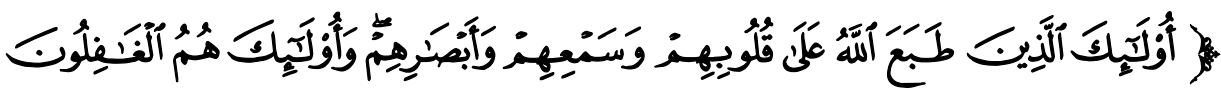

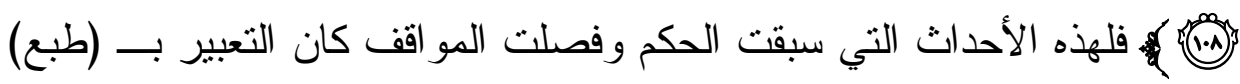
وكان شاملا للثالثة، و على ذللك فالطبع أثند من الختم، وسبق أن العلماء يثبهون الختم به، فهو في آية البقرة يتتاسب مع الإيجاز الجامع لموقفه، ولكنه يتميز بالتقصيل الذي يجعل للقلوب ختما وللسمع ختما، وكأن كلا منهما من نوع، حيث تكرر حرف الجر و الاستعلاء، وهذا آكد في شدة الختم، ولكنه لم يقو قوة الطبع، حيث جاء في آية النحل على الثلاثة دون تكرار هذا الحرف، وكأن الطبع حيث يقع يثبت استعلاؤه وتتحقق قوته دون حرف الاستعلاء. فتجلت شدة الختم بتكر ار الحرف، وفي ذلك يقول الزمخشري: " فإن قلـــ:

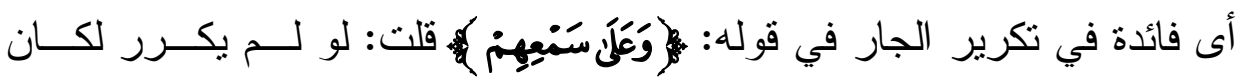

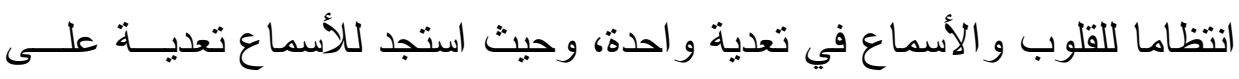
حدة كان أدل على شدة الختم في الموضعين." (') معنى ذلك أن الختم على القلوب له خصوصية تختلف عن خصوصية الختم

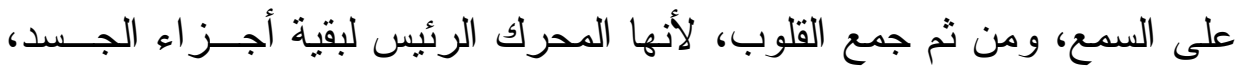

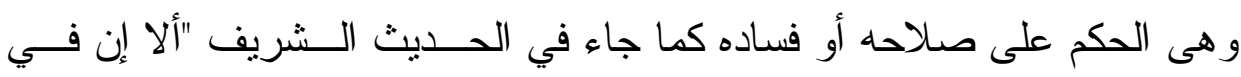
الجسد مضغة إذا صلحت صلح الجسد كله..." أما توحيد السمع فعلله العلماء بأنه

$$
\text { (1) الكثاف / / 17 طبعة دار المعرفة. . - - حاثشيته على الكثاف / / 1 1. }
$$


مصدر في أصله، و المصادر لا تجمع، ويمكن أن بعلل بأن حاسة السمع واحدة، وعملها ينحصر في التلقى.

ويَذْعَمَ ذلك الفهم قول السيد الثريف: " في توحيد السمع وجمع أخويه إثـارة لطيفة إلى أن مدركاته نوع و احد، ومدركاتهما أنو اع مختلفة(')" فما تسمعه الأذن فئن يحركه القلب إلى الخير أو الثر، و القلوب تختلف في ذللك فكـان أدعـى إلــى وهى جمعها، لذلك لما حكى سبحانه تفرق اليهود و عدم تآلفهم، قـال تعــالى بَأَسُهُ

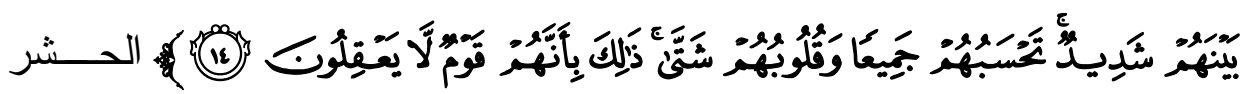

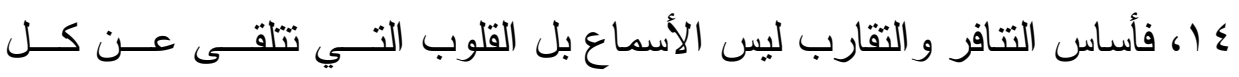

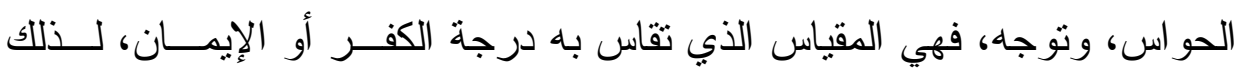

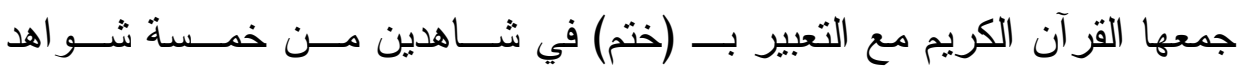
سأتحدث عنها.

ومع التعبير بـ (طبع) جاءت كلها مجموعة جمعا صريحا (قلوب) إلا قوله

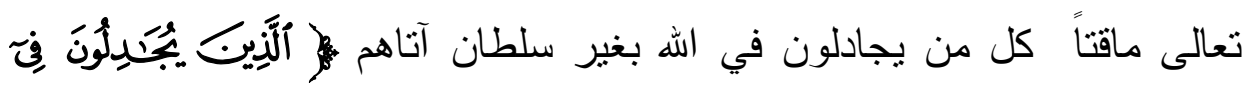

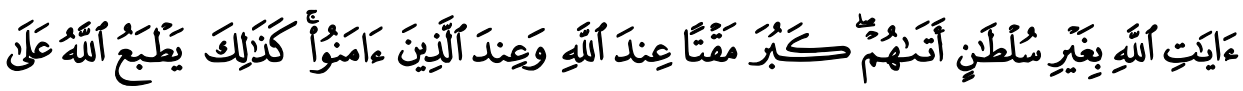

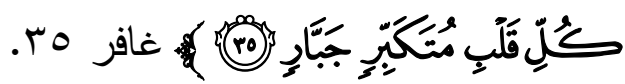

و هذا يحقق أن كل قلب متكبر جبار عليه طبع يختلف عـن غيـره، وهــــا

يرجع إلى درجة التكبر و التجبر، مما يوحى بأن هذا الطبع من الله عقـاب، و لا

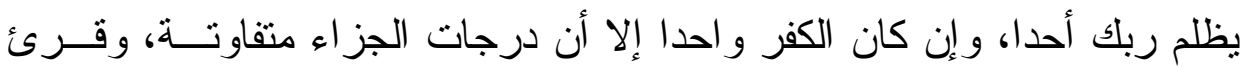

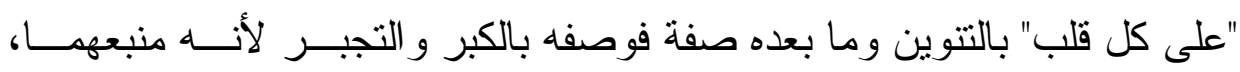


كقولهم: رأت عيني وسمعت أذني، وجوز أن يكون ذلك على حذف مضاف، أى كل ذى قلب منكبر جبار .. (')

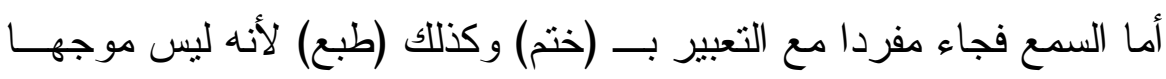

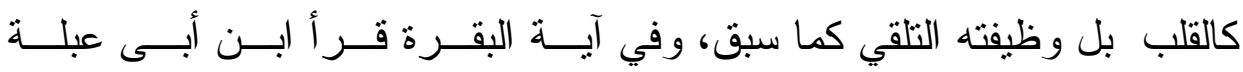

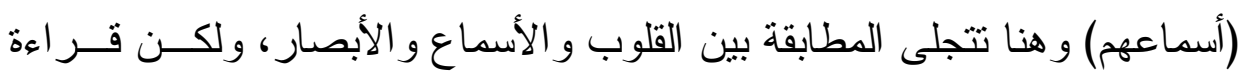

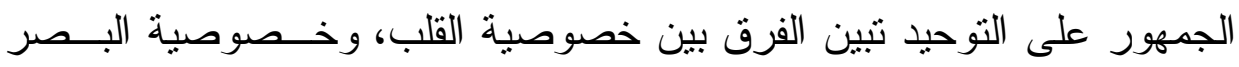

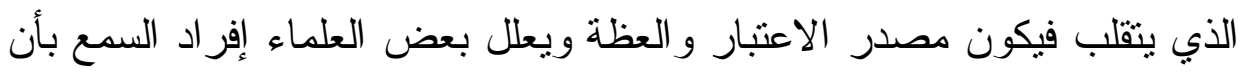

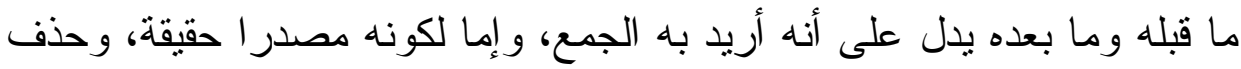

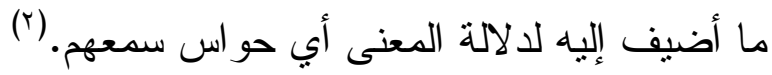

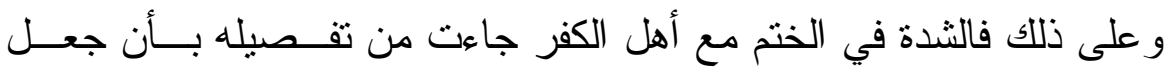

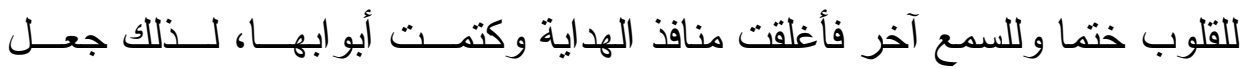

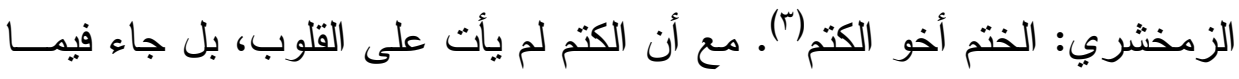

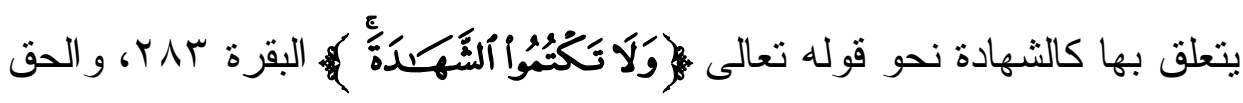

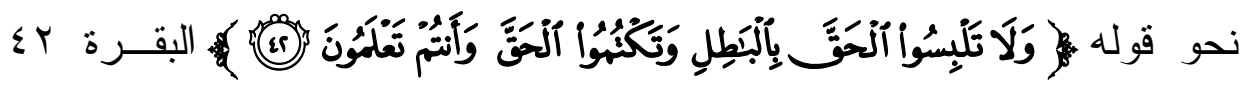

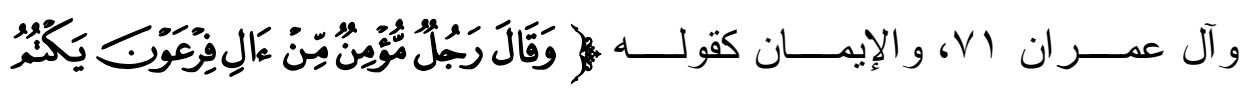

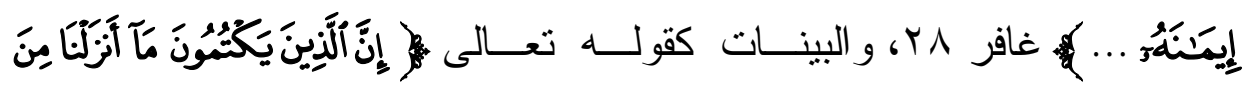

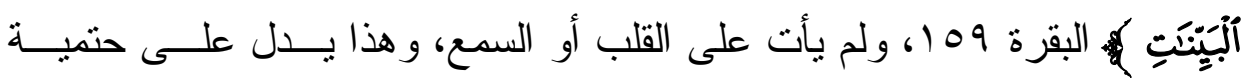

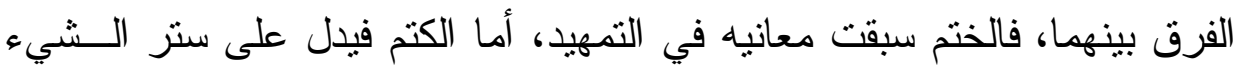

$$
\begin{aligned}
& \text { (1) (1) ينظر روح المعانى ع/r) }
\end{aligned}
$$

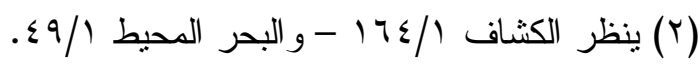

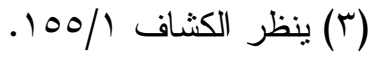


و إخفائه، وفرق بين أن يكتم الثيء فلا يخرج، وأن يختم على القلب أو الـسمع فلا يصل إليه شيء، ولا يخرج منه شيء.

ولكنه سبحانه في آية البقرة اختص الأبصار بالغـشـاوة وهــى كمــا قــال الر اغب: ما يعطى بـه الثيء.

و استعملت بهذا المعنى أيضا مع الختم على السمع و القلب في قولــهـ تعــالى

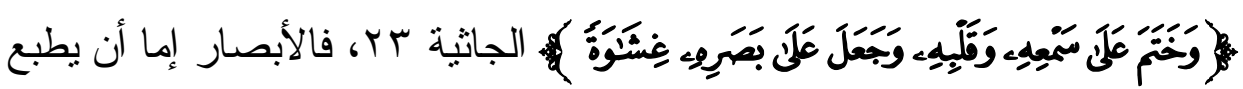
عليها كالقلوب و السمع - كما في آية النحل - فلا ينفذ إليها نــور الإيمــان و لا تعتبر بالحق حين تز اه، وهذا أقوى غطاء، وقد جاء في مرحلة تنتاسب مع بغيهم

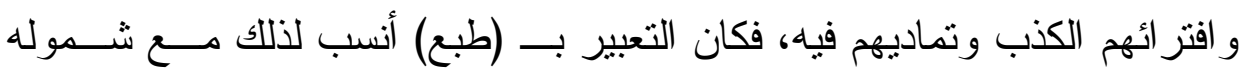
للثناثة القلب و السمع و البصر . أما تعليل جعل الغشاوة على الأبصار في آيتي البقرة والجاثية فقد بينها ابــن

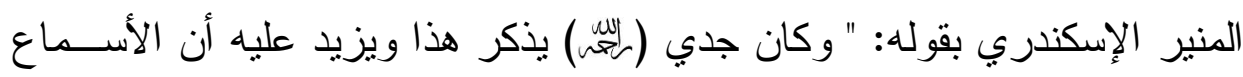

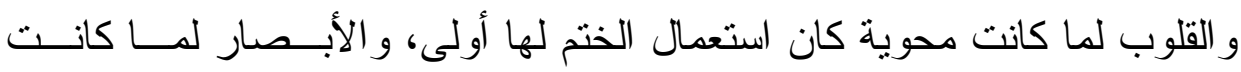
بارزة، و إدر اكها متعلق بظاهر ها كان الغشاء لها أليق (') ". تعليله هذا يفيد أن القلوب و الأسماع تحوي أمور اكثيرة، وبالنسبة لهم تحوي ضلالا يحول بينها وبين أن تستجيب لله سبحانه فكان استعمال الختم لهـــا ألبــق، بخلاف الأبصار فإنها تزى وتتصرف عما رأته، أو لا تعتبر بما رأتــه، وهــــا

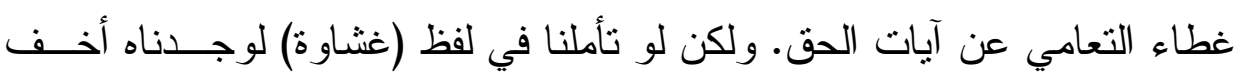

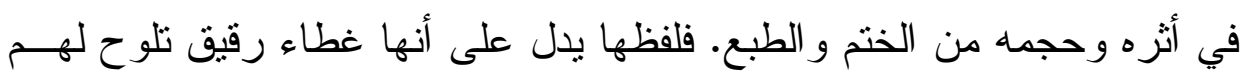
الحقائق منه وتختفي، ولكنهم لا يعتبرون بما يظهر، وفي هذا إمهــال لهـــ؛ لأن 
الاعتبار يكون بالنظر أكثر من السمع، وهو الوسيلة إلى اعنبار القلب كما قـال

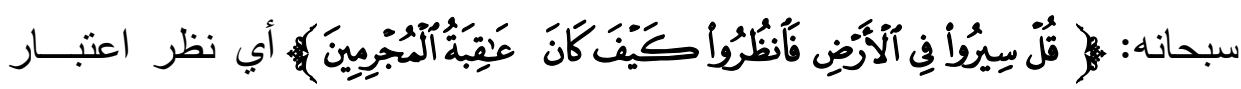

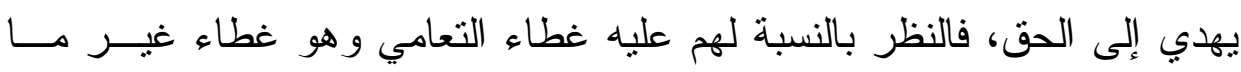

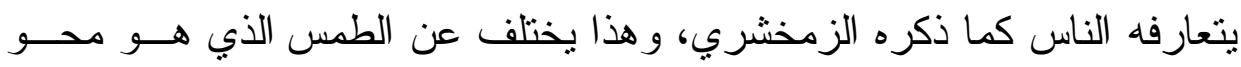

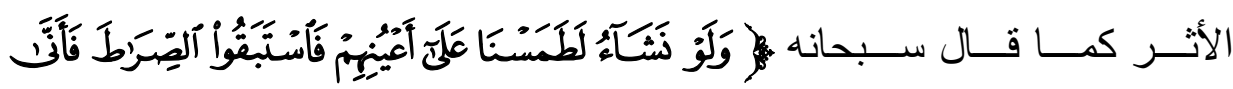

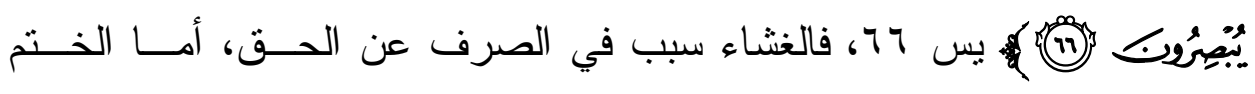

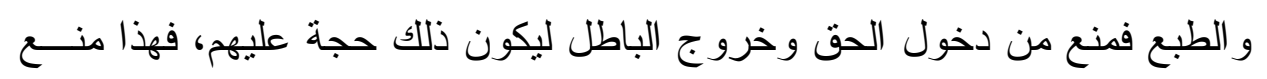
كامل.

أما الغشاء فغطاء يحول دون رؤية الحق فقط، وضحه الزمخشري في بيان

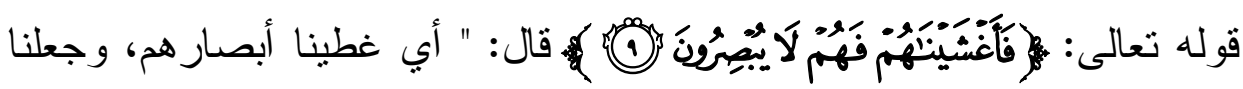
عليها غشاوة عن أن تطمح إلى مرئي "( (')

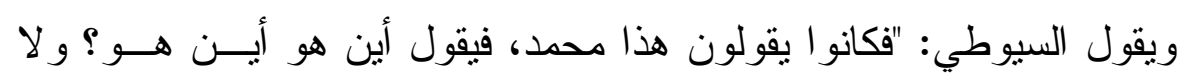

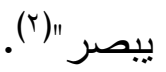

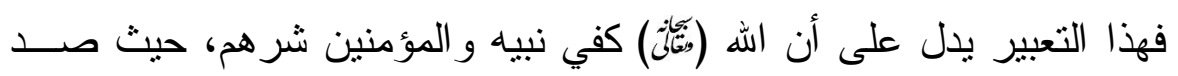
أنظار هم عنهم، وليس ثمة ختم و لا طبع. لئ.

و وعلل السيد الثريف هذا الفرق بين الختم و الغثاوة بقوله: "قفل لهــــــــان

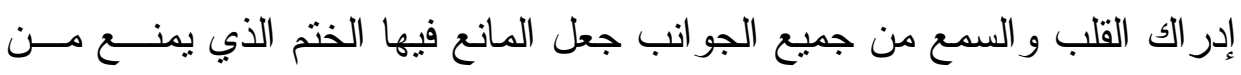

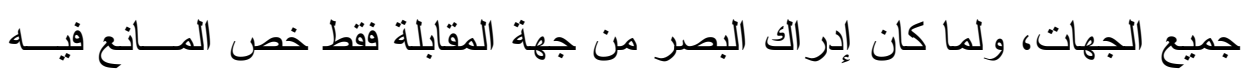

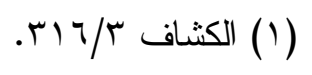

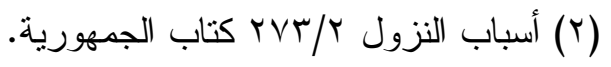


بالغشاء المتوسط بين الر ائي و المرئي." (') ولكنها غشاوة لا يعلم مـــداها إلا الله، لذلك جاءت منكرة للالالة على أنها غطاء معين لا يعلمه أحد، و أفلح الزمخشري حيث قال: غير ما يتعارفه الناس، غير أنه جعل ذلك كله من باب المجاز ، وتبعه كثير من المفسرين، حيث فال في ذللك: "فإن قلت: ما معنى الختم على القلــوب

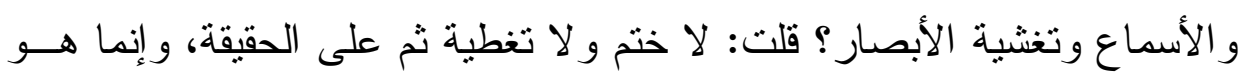

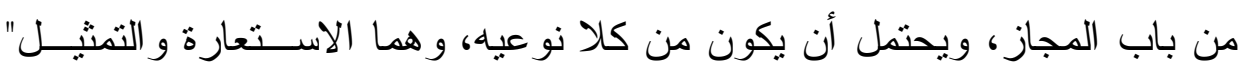
ووضح ذللك بما يفيد أن قلوبهم لإعر اضها عن الحق وصدها عنه كأنها مستوثق بنق

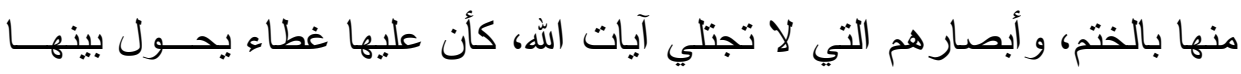

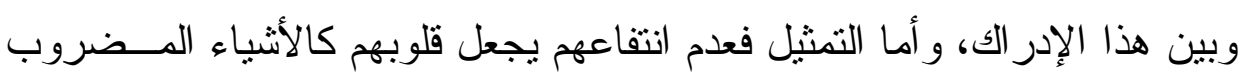
عليها بالختم و التغطية. (r) ولإن غير أن الثهاب الخفاجى علق عليه بأنه يقتضي أن إطلاق الختم على بلوغ الآخر معنى مجازي، وهو خلاف المعروف في الاستعمال و لأنه يقتضي أيــضا أنه مأخوذ من الاستيثاق، وكلام الر اغب صريح في أنه مجاز بر أسه، ثم أجــاب

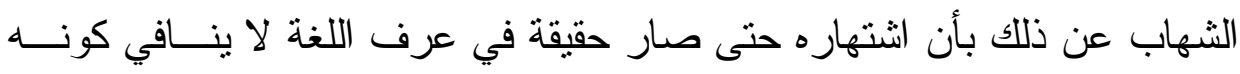

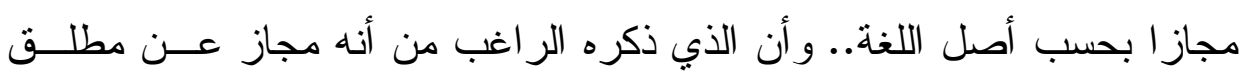

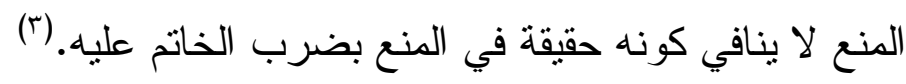
كأن الثهاب أر اد أن يتوسط بين الأقو ال فو افق على اعتبار المجاز وبين أنه لا ينافي الحقيقة.

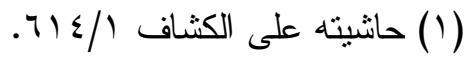

$$
\begin{aligned}
& \text { (Y) الكثاف (Y) }
\end{aligned}
$$

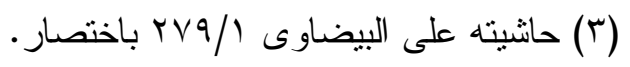


وأرجح كون الحقيقة هنا أولى ولا داعي لاعتبار المجاز و التأويل، لأن الذي خلق القلوب و الأسماع والأبصار قادر على أن يختم عليها فلا تستجيب، ويغشي ولي عليها فلا ترى الحق، ويكون الختم و التغشية نوعا من العقــاب بــسبب كفــر هم بآيات الله، وقد ارتضيت في الدراسة كلها منهج أهل السنة؛ لما رأيته من دلالــــة المادتنن ( ختم وطبع) في دقائق السياق.

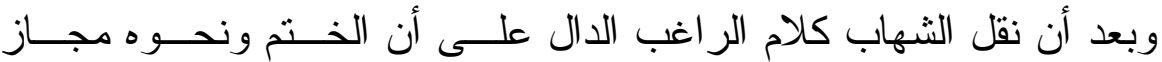

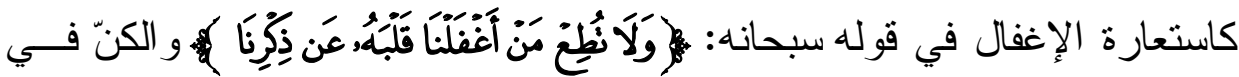

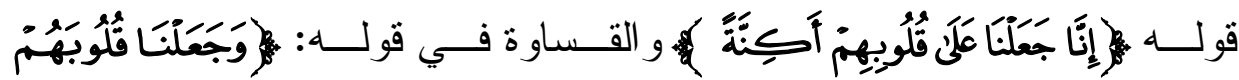

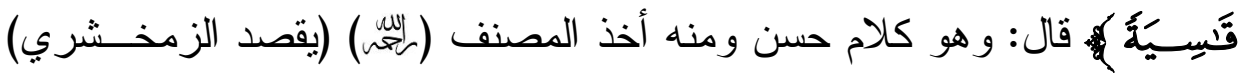
ثم اعلم أن البزار روى حديثا مرفوعا عن ابن عمر فيه أن الطابع معلق بقائمـــة العرش، فإذا عمل العبد بالمعاصي واجتر أ على الله بعث الله الطابع فيطبع علـى قلبه فلا يعقل بعد ذلك شيئا، فقيل إنه روى مثله في كثير من الأحاديث فحملهــا من لا يتضلع من الحديث على المجاز ، والأقوى كما في شرح الــسنة للبغـوي إجر اؤها على الحقيقة إذ لا مانع منها، و التأويل خلاف الأصل..."(() وهذا يبـين

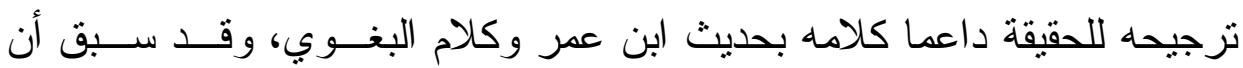
رجتها، ويدعم ذلك الترجيح أيضا ما ذكره فخر الدين الرازي من أن هذه الآية في قوم من الكفار عجل الله لهم العقوبة بهذا الختم والطبع في الدنيا، كما عجـلـ

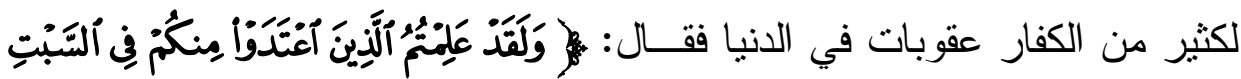

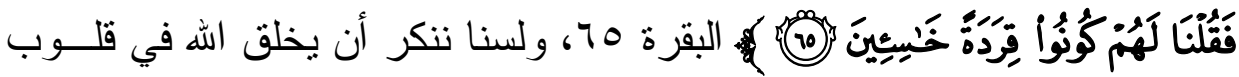

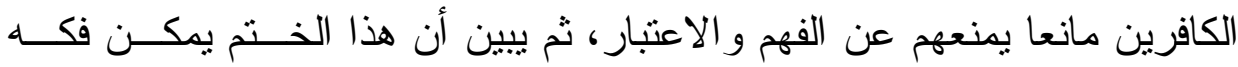

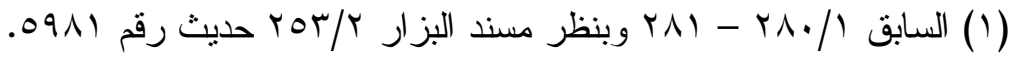


بالإيمان، أي يزيل الكافر تلك السمة عن قلبه بأن يأني بالإيمان ويتــرك الكفــر ،

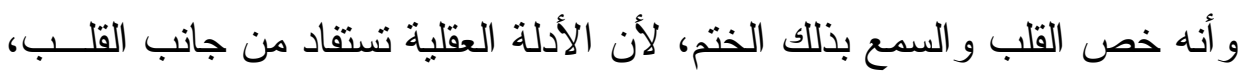
و الأدلة السمعية تستفاد من جانب السمع.. أما الغشاوة فحقيقتها الغطاء المانع من الإبصار ، ومعلوم من حال الكفار خلاف ذللك، فلا بـ من حمله علــى المجــاز ،

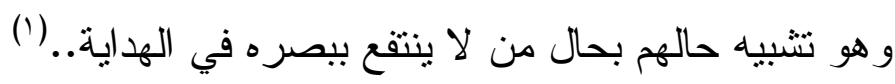
معنى ذللك أنه يو افق على اعتبار الختم حقيقة ولكن الغشاوة لا تصلح فيهــا الحقيقة، ولكن لو أنعمنا النظر لوجدنا أن الغشاوة أيضا جعلها اله على أبصار هم بطريقة لا تحول بينهم وبين كل رؤية، و إنما تحول بينهم وبين ما لا بريد الله أن

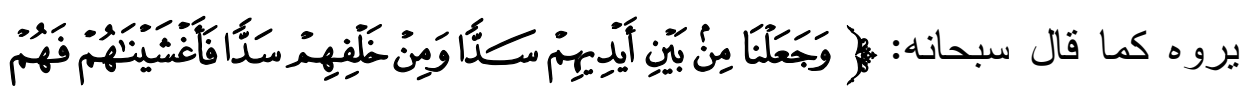

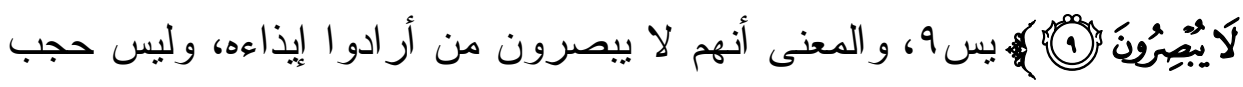
الرؤية على سبيل العدوم، وقد سبق أن الزمخثري بين سبب تتكير الغشاوة بأنها نوع من الأغطية غير ما يتعارفه الناس، و إذا كان الأمر كذلك فما الداعى إلـى

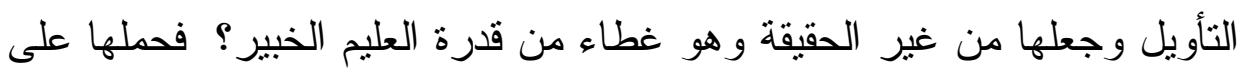
الحقيقة كالختم أولى بكل هذه الأدلة.

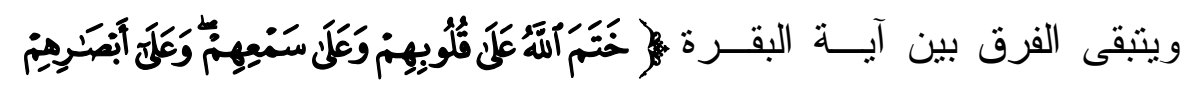

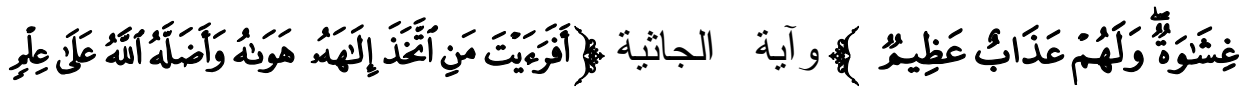

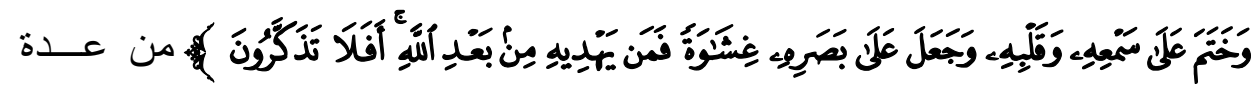

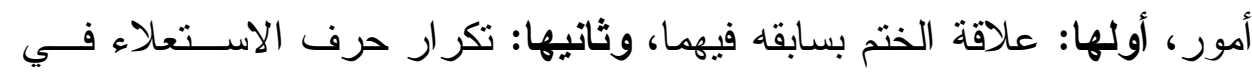
الأولى دون الثانية، وثالثها: ذكر لفظ جعل في الثانية دون الأولــى، ورابعهــا: نهاية الآيتين و علاقته بأسباب الختم، وبالإجابة عن ذلك ينتهي القول فيهما.

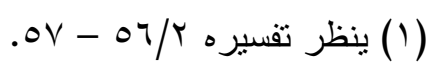


وبيان ذلك: أنه لما كان الحديث في بداية سورة البقرة عن الطوائف التثلاث

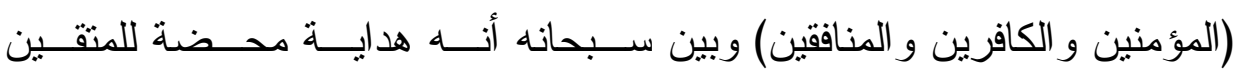
بأوصافهم المذكورة في فاتحة السورة، وأن الكافرين اســتوى عنــدهم الإنــذار

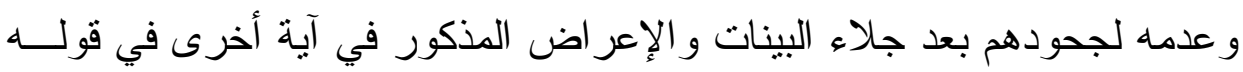

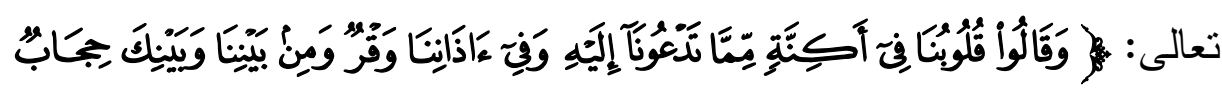

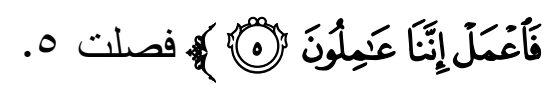
وذكر الرازي أنهم رؤساء اليهود المعاندون الذين وصفهم الهه تعالى بــأنهم يكتمون الحق وهم يعلمون ·() فمن الطبيعي أن من كان هــذاء حـــالهم يـستوي عندهم الإنذار و عدمه، وفي ذللك تسكين لنفس الداعي الحريص علــى إيمــانهم

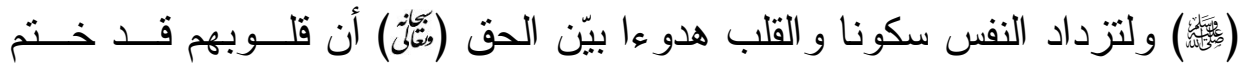

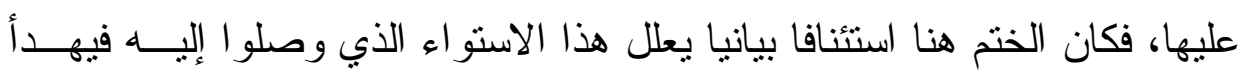

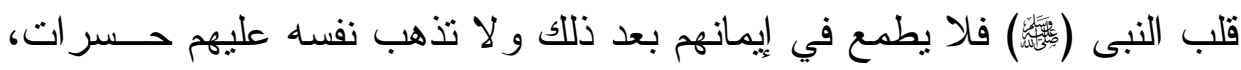
ومن ثم كان حرف الاستعلاء (على) الدال على استعلاء الختم وتمكنه، ولعل هذا التمكن الناجم من هذا الحرف هو الذي جعل الزمخشري يـسـوي بــين الخــتم

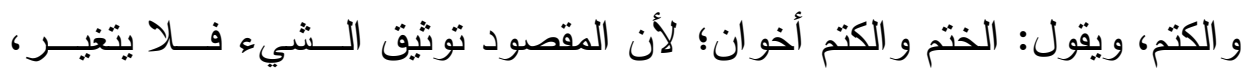
وتكرر هذا الاستعلاء مع السمع تأكيدا لنفي وصول الحق إليهم من أي طريــق، فإذا كان القلب يأبى الحق بما عليه من ختم فإن السمع يشّاركه هذا الإباء، فكــان

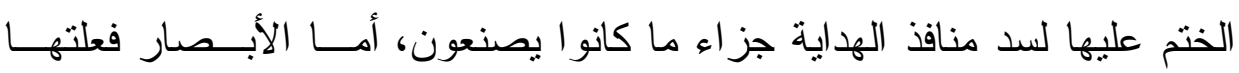

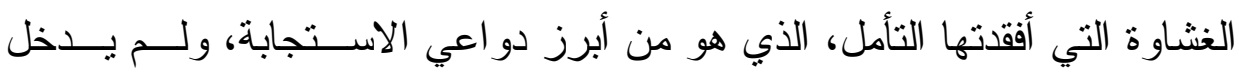
حرف الاستعلاء على القلب في آية الجاثية؛ لأن الحديث عن الضال، فيكفيه ختم

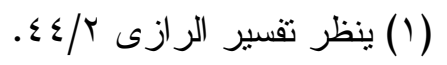


و احد على السمع و القلب يستويان به، وبدأ في آية البقرة بالقلب مر اعاة للحــديث

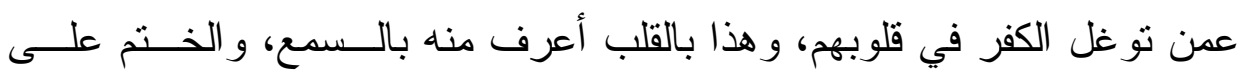

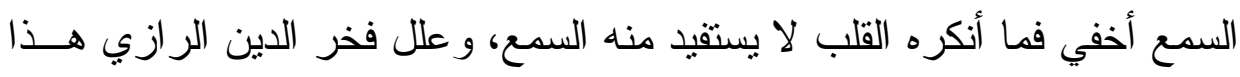
التقديم تعليلا دقيقا فبين أنه في آية الجانية قدم ذكر السمع على القلب، وفي آيـــة

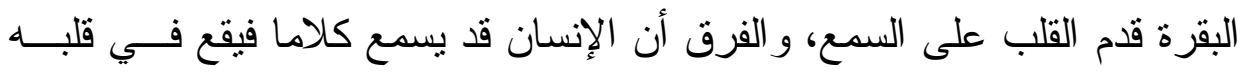

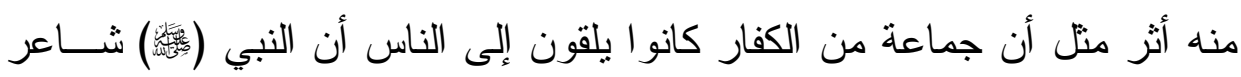
وكاهن، و أنه بطلب الملك و الرياسة، فالسامعون إذا سمعو ا ذلك أبغضوه، ونفرت قلوبهم عنه، و أما كفار مكة فهم كانو ا يبغضونه بقلوبهم بسبب الحـسـد الـشنديد،

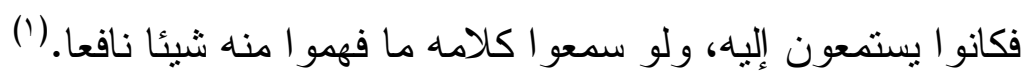
ومعلوم أن الجاثية مكية، و البقرة مدنية، و الرازي بنى تعليله على ذلك، أمســا. البقاعي فبين أنه "لما سوي بين الإنذار و عدمه كانت البداءة بالقلوب أنسب تسوية لية لئه

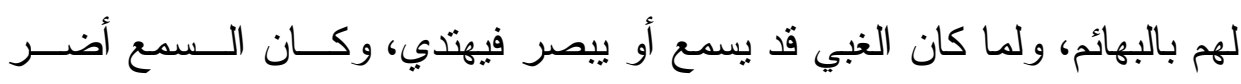
لعمومه وخصوص البصر بأحو ال الضياء نفي السمع ثم البصر تسفيلا لهم عـنـ لهن حال البهائم، بخلاف ما في الجاثية فإنه لما أخبر فيها بالإضلال، وكان الــضال

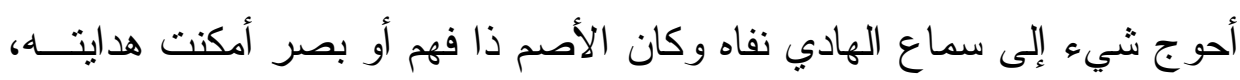

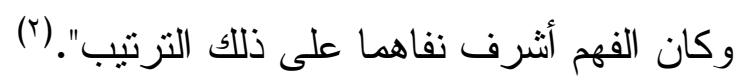

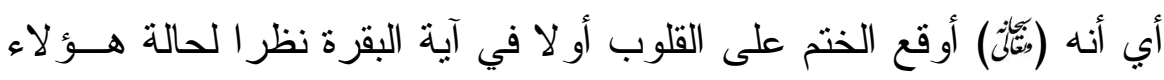

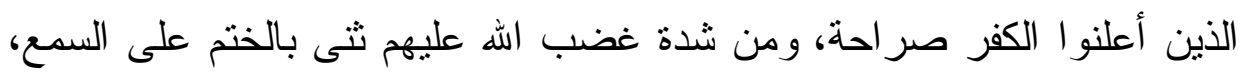
حتى لا يكون لهم إلى فض هذا الختم سبيل، وتلث بجعل الغشاوة على أبصار هم ليتوقف مجال الاعتبار، الذي قد يكون داعيا للاستجابة إلى الحق.

$$
\begin{aligned}
& \text { (1) ينظر تقفيره TV/TV. } \\
& \text { (ץ) نظم الدرر /N// }
\end{aligned}
$$


أما الختم في آية الجاثية فقد وقع على السمع أولا ثم القلب ثانيا، لأن الآيات قبلها تتحدث عن نعم الله على بني إسر ائيل وبغيهم بينهم، ثم بيان حالة من اتخذ إلهه هو اه فتخبط في ظلمات الجهل مما يؤكد أنه في ضلال يعلمه كما فال

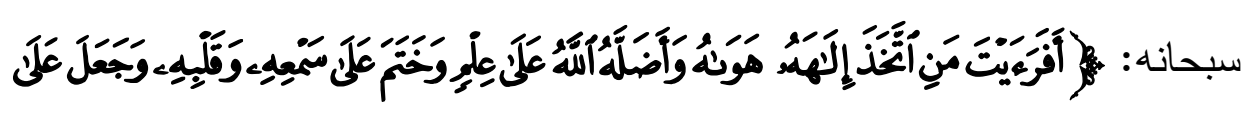

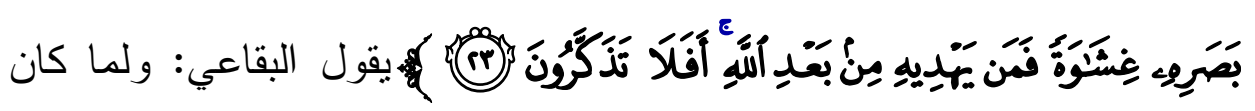
الضال أحوج إلى سماع صوت الهادي منه إلى غيره، وكان من لا ينتفع بما هو له في حكم العادم له قال: "وختم على سمعه" فلا فهم لله في الآيات المسموعة ولما كان الأصم قد يفهم بالإشارة قال: "وقلبه" ثم قال: "وجعل على بصره غشاوة" بحيث لا ييصر الآيات المرئية، وترتبها هذا لأنها في سياق الإضلال. (')

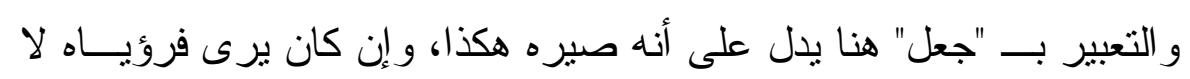
نفع فيها، و التعبير هنا مع الضال أخف من الاستعلاء "على" هناك مــع الكــافر كفر ا صريحا، ولذلك ختم المشهد في آية الجاثية بييان أنه يمكن هدايتــه ولكــن ليس من قبل غير الله، وأن توهم ذلك من غير الله مستبعد مستتكر، ومن ثم كان التذييل بهذا الاستفهام "فمن يهديه من بعد الله" ثم يتبعه إنكار آخر لمن لم يتذكر

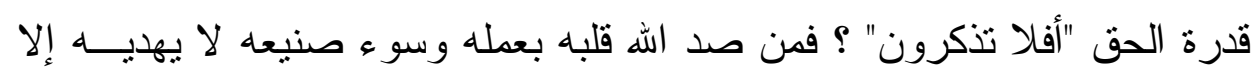

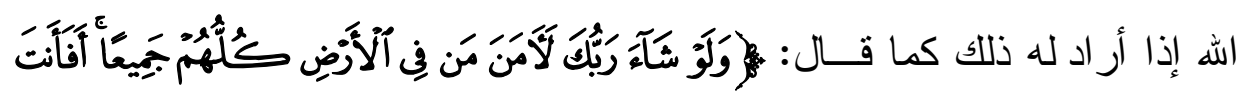

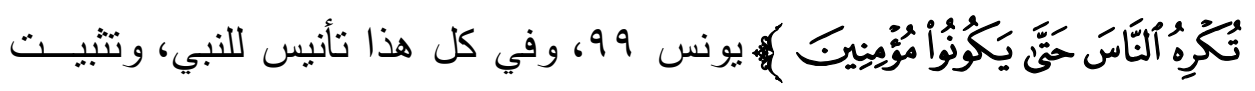

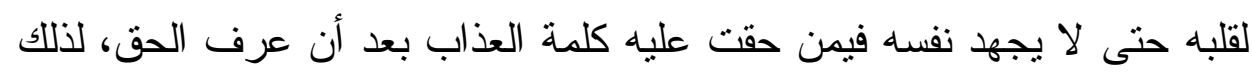
تتاسب هذا الختام مع الحديث عن الضال الذي اتبع هو اه، بخلاف آية البقرة التي

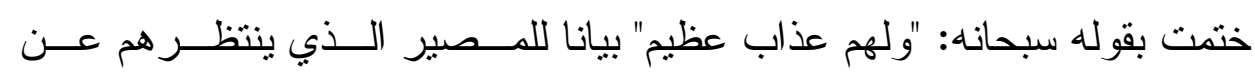


استحقاق، لذلك وصفه بأنه "عظيم" تتاسبا مع قوة كفر هم، وتوغلهم فيه، و إحاطته بظاهرهم وباطنهم و هذا يتتاسب مع إجمال القر آن الكريم في مقدمة سورة البقرة لهذه الطو ائف الثالث: طائفة آمنت فاهتدت وز ادها القر آن هدى، وطائفة كفــرت حتى استوى عندها الإنذار و عدمه، فكان لها هذا العذاب العظيم، وطائفة أظهرت خلاف ما أضمرت فكان لها العذاب الأليم وفي كل سياق ما يناسبه. وبهذا ينجلي الفرق بين خصوصية التعبير بـ (خــتم) فــي آيتـي البقــرة و الجاثية مع ما بينهما من تفاوت في ترنيب المختوم عليه. 


\section{المبحث الثثاني \\ استعمال (ختم) على القلوب واختصاصها بالأفواه}

ما سبقت در استه كان في اثتنز الك القلوب و الأســـاع فــي الخــتم عليهــا،

و استعمال الغتشاوة على الأبصار إما بحرف الاستعلاء، و إما بفعـلـل الــصيرورة

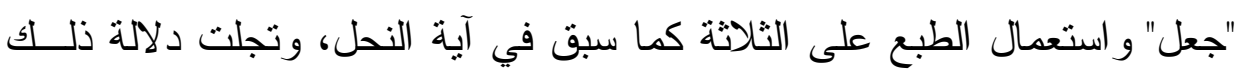

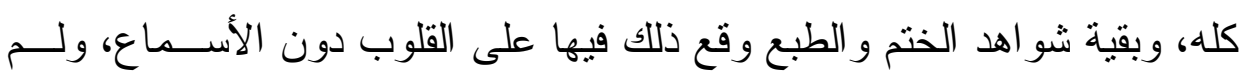
تتعرض لذكر الأبصار ، باستثناء (ختم) فقد وقعت على الأفو اه في شاهد و احد. فجاء الختم على القلوب فقط في شاهدين ولكل منهما مقامه: الأول في سورة الأنعام، ومقامه التذكير بقدرة الله تعالى، ودليل صحة هــذا

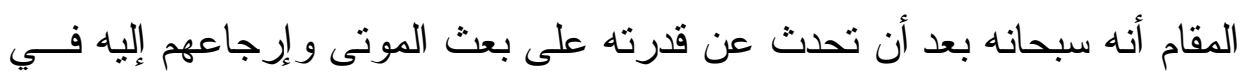

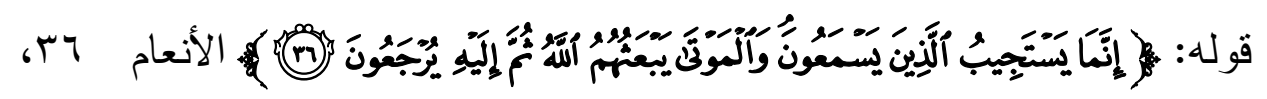

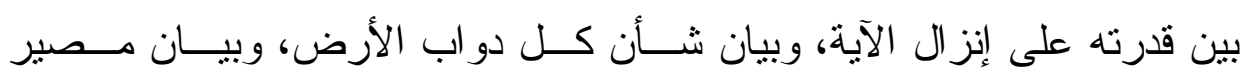

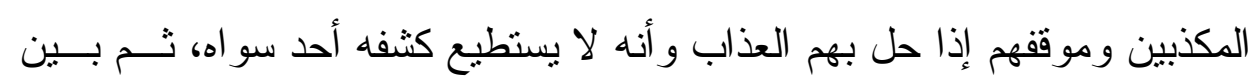

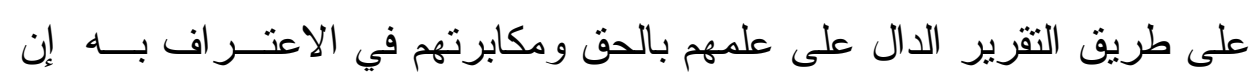
سلبت منهم النعم الدالة إلى الحق فمن غيره يأتيهم بها؟ وذلك هو موطن الـشـاهد

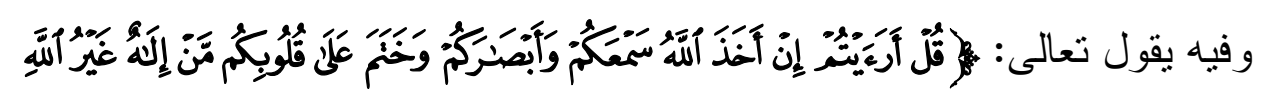

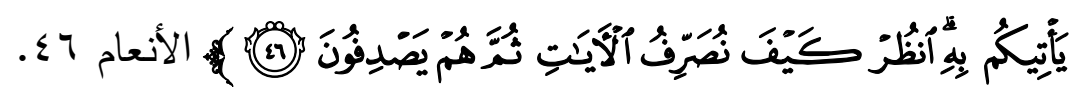

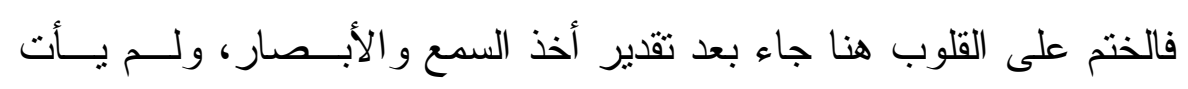
الحديث عن السمع بالختم، وعن الأبصار بالغشاوة كما سبق، بل تحدث عنهــــا

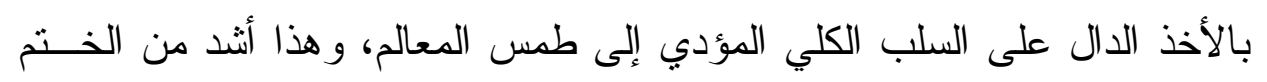


المسلط على القلوب، ولو يصلح فيها الأخذ مع بقاء الحياة لعبر به، ولكـن جـــاء التعبير بـــ "ختم" الدال على إغلاقها.

أما لفظ أخذ فيأتي بمعنى التتاول، وبمعنى التمكن كما فــي قولــهـ تعــالى:

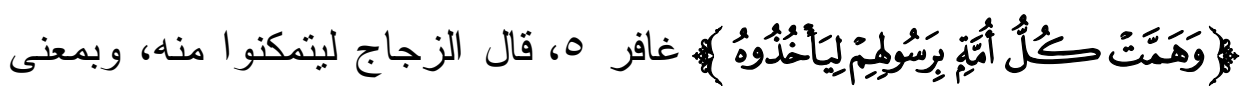

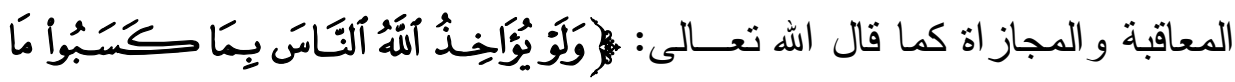

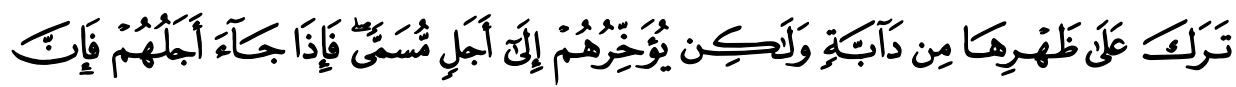

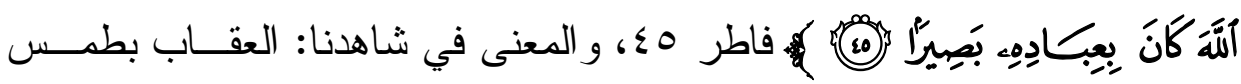
السمع و البصر ، و التعبير عن ذلك بـــ "أخذ" زيادة في النكال و الوعيد، وهو أثـــــ

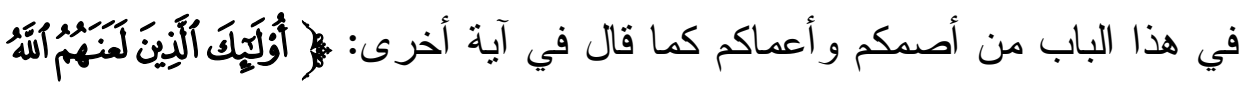

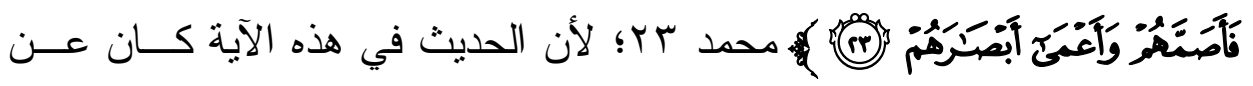
الذين في قلوبهم مرض ولم يصدقو الهه في قول و لا عمل فكان العقــاب قاطعـــا صريحا، أما في شاهدنا فالسياق سياق تقرير وتأنيب وتهديد، لذا كان التعبير بـ "أخذ" دالا على القدرة، ومناسبا لحال من أمد الله لهــم مـــع بغــــهم وطغيــانهم

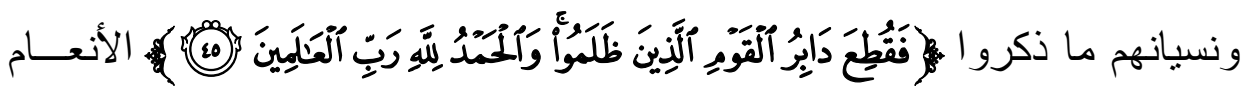

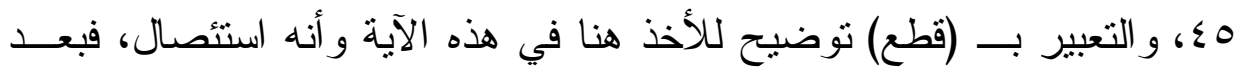
هذا الأخذ الكلي القاطع لدابر من ظلم قبلهم جاء هذا التتكيــر بالأخــذ الجزئسي المناسب لسياق التهديد، عسى أن يكون ور اءهر رادع.

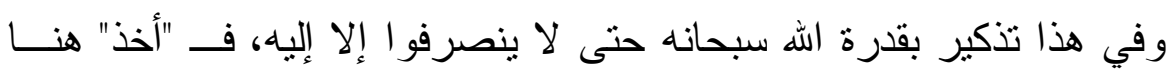

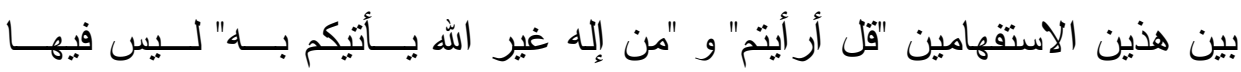

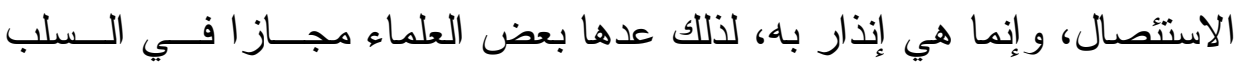
و الإعدام، معلا ذلك بأن السلب من لوازم الأخذ بالنسبة إلى المأخوذ، فهو مجاز 
مرسل، ثم قال: ولك أن تجعله تمثيلا بتشبيه هيئة إعدام الخالق بعـض مو اهـبـ مخلوقه بهيئة انتز اع الآخذ شيئا من مقره، فالهيئة المشبهة هنا عقلية و المــشبهة

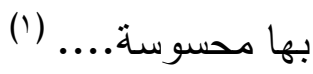

و أرجح إجر اء الأخذ في هذا المقام على حقيقته بمعنى عقاب الله بسلب مـــا

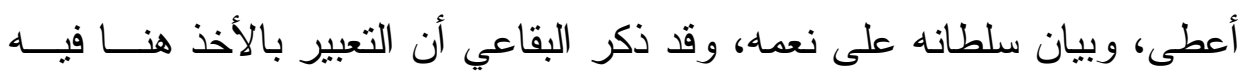

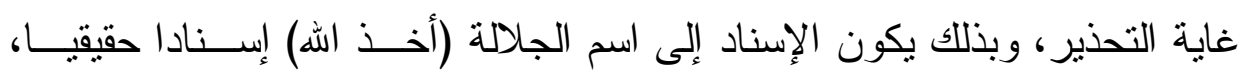

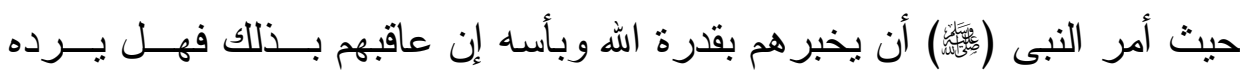
عليهم غيره؟

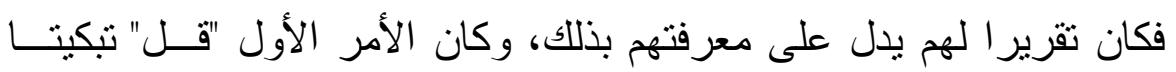
وتعنيفا لهم و الأمر الثاني الذي ختمت به الآية "انظر كيف نصرف الآيات ثم هم

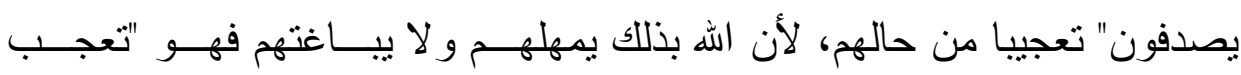
مصحوب بمشهد الصدوف المعروف عند العرب و الذي يذكرهم بمشهد البعيـر المؤوف فيثير في النفس السخرية و الاستخفاف و العزوف".(؟)

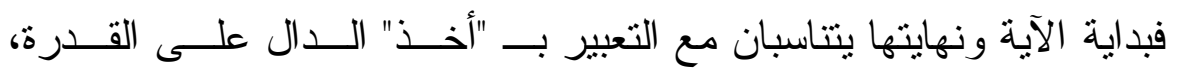
و المقصود به نبذ الشرك و أن ما يشركون به لا شأن له، ولذلك وقع الأخذ على التى

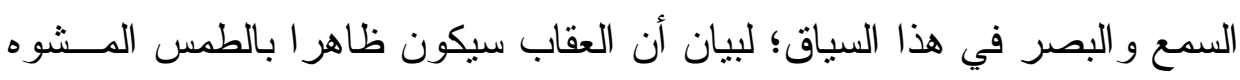

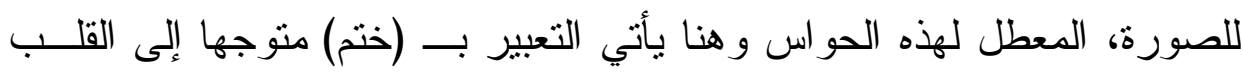
كعادته في كتاب الله، ودلالته بعد إيقاع الأخذ على وسائل الفهــــ و الإدر الك تـــل على التدرج في الإنذار بالعقاب.

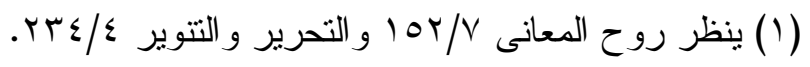

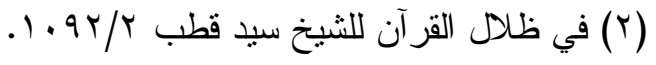


فالختم على ما هو أعم و الأخذ على الأخص، ولذلك قيل:" يجوز أن يكــون الختم عطفا تقسيريا للأخذ فإن البصر و السمع طريقان للقلب منهما يرد ما يــرده ولاهي من المدركات، فأخذهما سد لبابه بالكلية، وهو السر في تقديم أخذهما على الخــتم عليه، و اعترض بأن من المدركات ما لا يتوقف على السمع و البصر، ولهذا قال

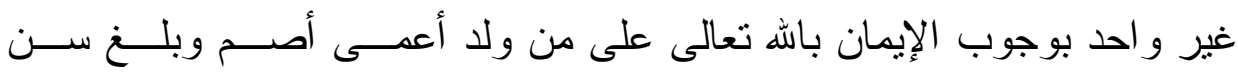
(التكليف". (1)

ويمكن الرد على هذا الاعتر اض بأن المقصود هنا حالة الأخذ عقابـــا لمــن هذا شأنه، ولذلك جاء (ختم على قلوبكم) تفسير ا مناسبا لهذه الحالة، فليس كل من

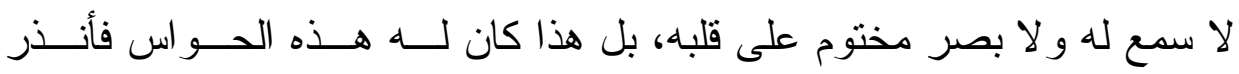

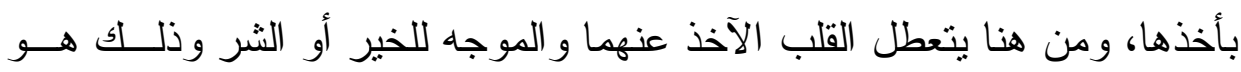
الختم، وهذا هو المقام الأول في شاهدي الختم على القلب فقط دون السمع. أما المقام الثاني فمقام الحفظ و الربط:

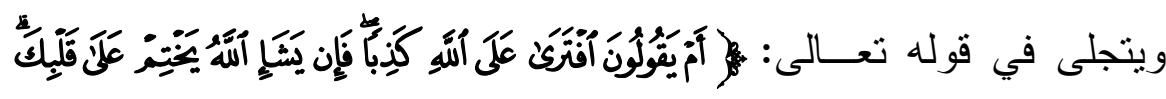

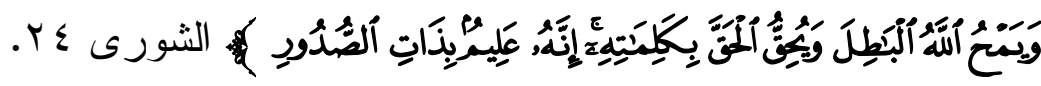

فالختم في هذه الآية فيه اختلاف في معناه، ذكر الدامغاني: أن المعنى هنــــا:

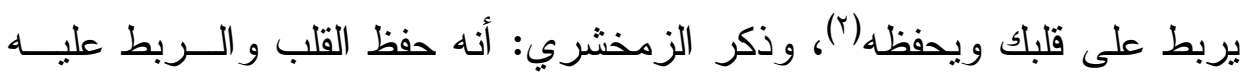

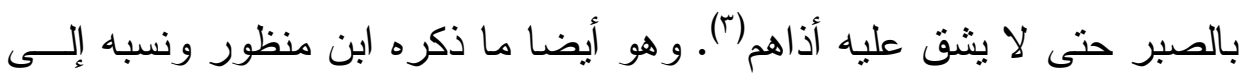

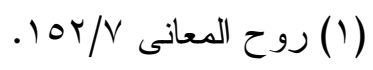

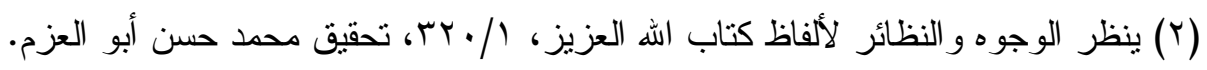

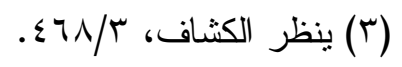


الزجاج فقال: قال الزجاج: معناه إن يشأ الله يربط على قلبك بالصبر على أذاهم،

و على قولهم افتزى على الله كذبا. (')

و هذا أفضل الوجوه عندي؛ لأمرين: أولهما: أن الكلام في ســياق التبـشير

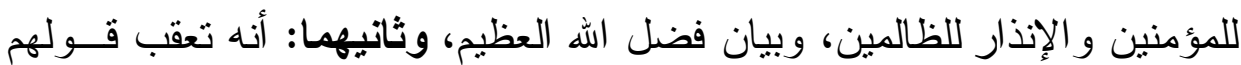

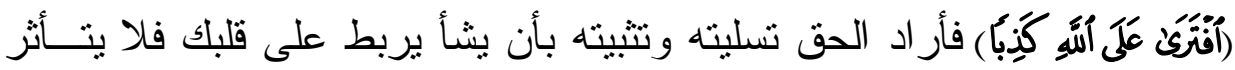
بقولهم هذا، و أيضـا يرجحه ما ذكره الزمخشري تعقيبا على الآية: "وهذا مـــؤداه

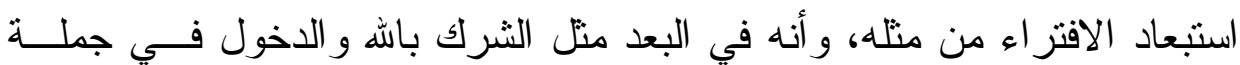

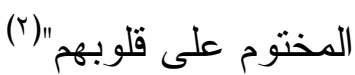

فالختم هنا على ذلك كله ربط، وحفظ كما قال الدامغاني وغيره...

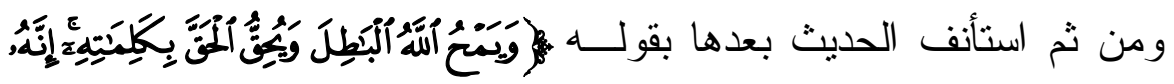

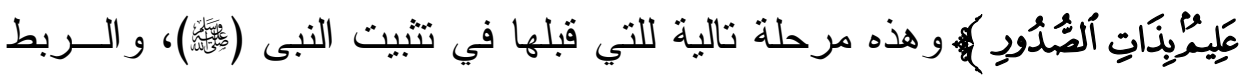
على قلبه بمحو باطلهم و إثبات الحق الذي هو عليه.

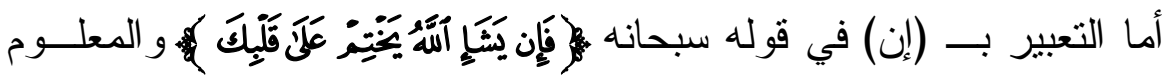

أنها تقيد الثك فقد علله شهاب الدين الخفاجي بقوله: "أتى ب(إن) فــي موضــع

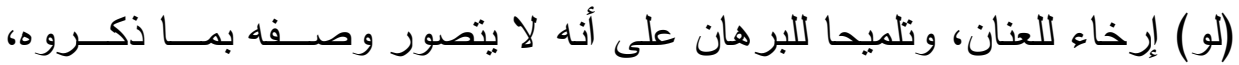

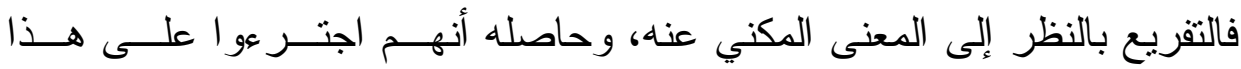
المحال؛ لأنهم مطبو عون على الضلال، فعليك بإمعان النظر فإن هذه الآية مــن أصعب ما مر بي في كلامه العظيم. وفقنا الله لفهم معانيه، وعدى الإشعار بعلى لئى

$$
\text { (1) (1) لسان العرب (ختم). }
$$


لتضمنه معنى البينة أو الدلالة"(')، و لا ريب أن هذا فهم دقيق جاء تعليقــا علــى قول الزمخشري: "إن هذا الأسلوب مؤداه استبعاد الافتز اء من مثله "، فعلى ذلك هلك

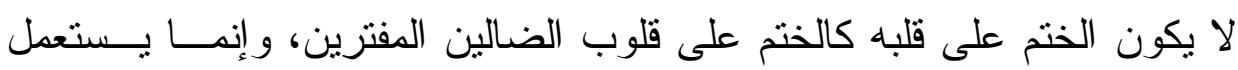

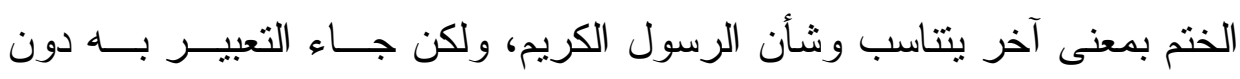
الربط أو الحفظ: مشاكلة لما يحدث لهم، وتماثيا مع أهو ائهم ليزدادو ا ضلالا مع ونع

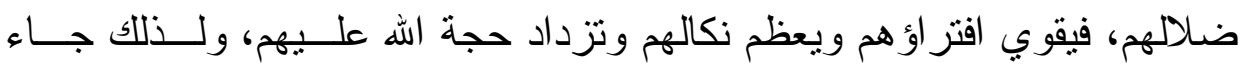
التعبير أيضا بفعل المشيئة المحذوف مفعوله، أي إن يشأ الله الختم على قلبك ختم عليه فلا يبالي بسوء صنيعهم، و هذا يؤكد تحسره عليهم و تأثره بتصر فاتهم كمـــا

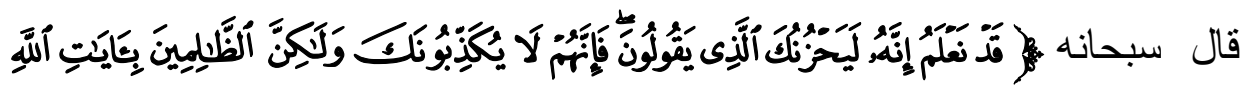

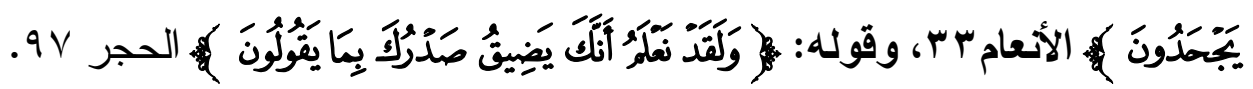

$$
\text { وتأتي (ختم) بمعنى "منع" في مقام الإضلال. }
$$

وذلك في سياق نهيه - سبحانه- عن عبادة الشيطان و الأمر بعبادة الرحمن، ومع ذلك أضل الشيطان قوما كانو اعتاة كالجبال، وذلك جلي في قوله تعالى

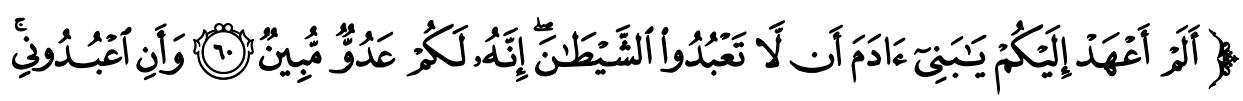

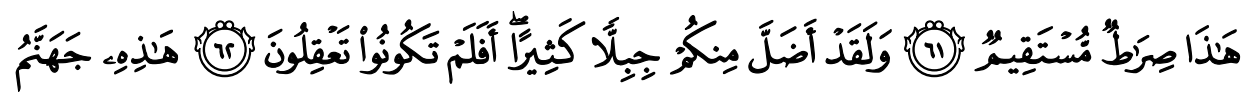

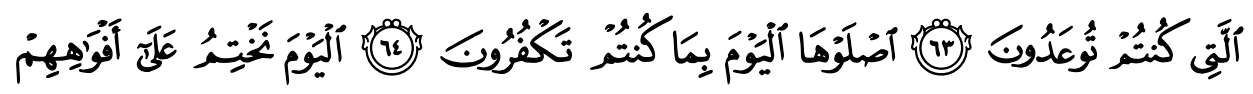

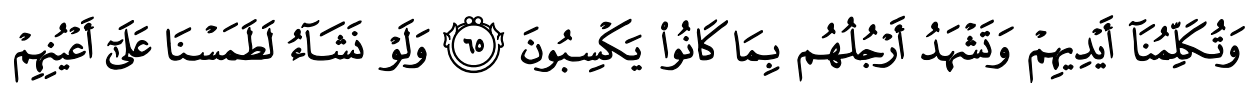

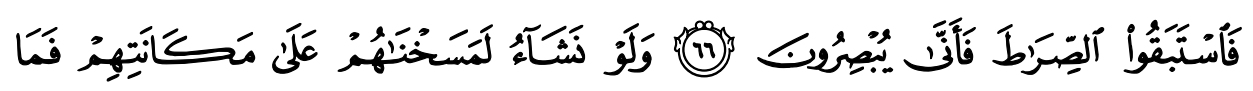

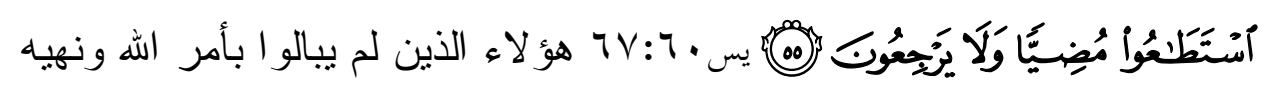

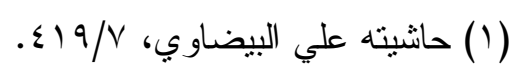




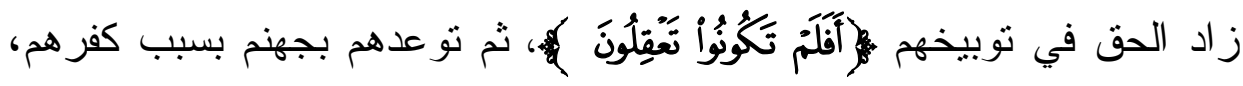

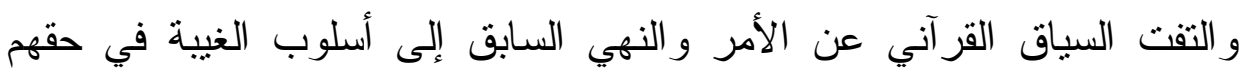

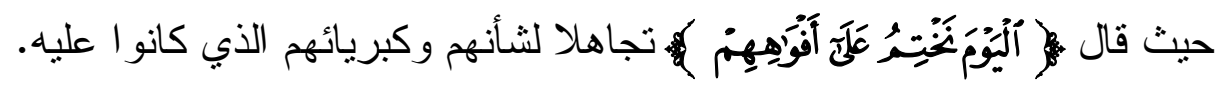

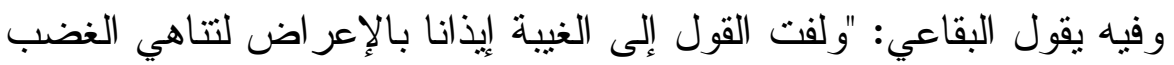

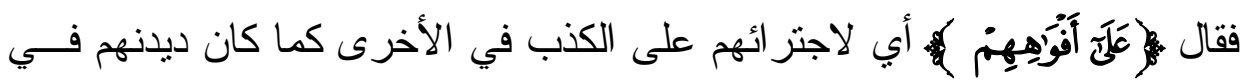

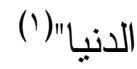

فالختم على الأفو اه هنا بمعنى منعها من الكــلام، و إثباتـــهـ للأليــد، و إثبـــات

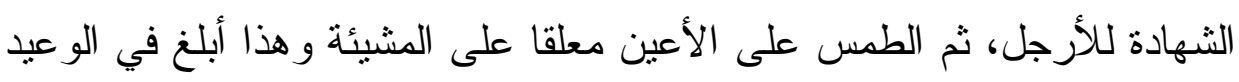

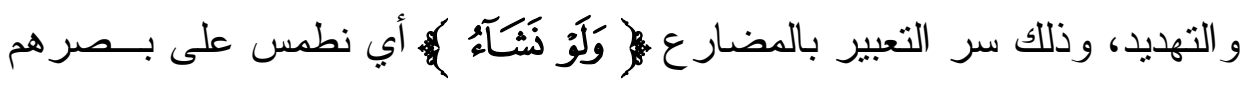

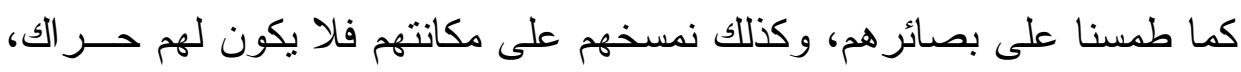

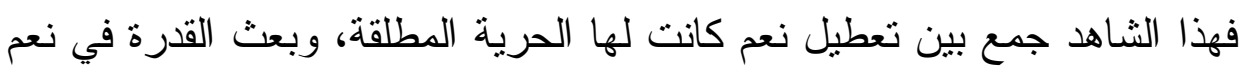

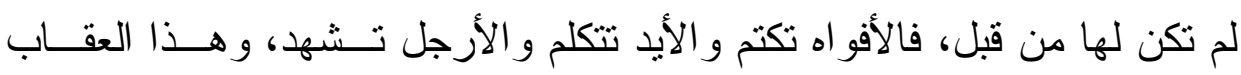

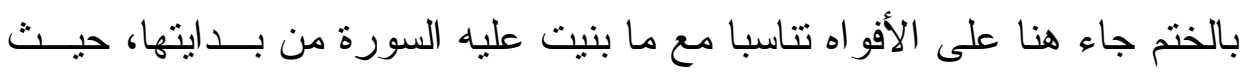

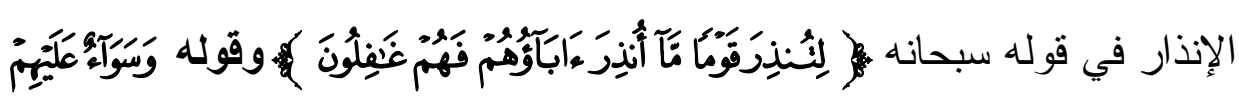

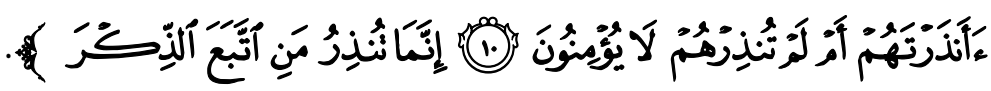

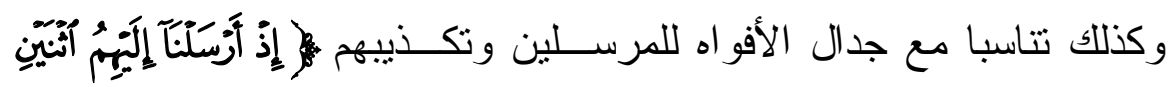

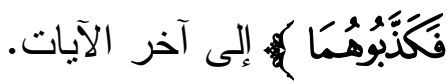

فنظير هذا: الجدال و التكذيب و النطير و التهديد للرسل، وكل ذلك صادر من

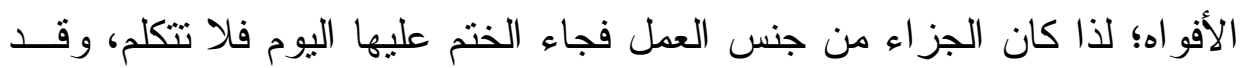


كان يمكنها أن تتكلم بالحق ولكنها أعرضت وجاءت بالباطل، فعقابهــا اليـوم أن يختم عليها وتتقل وظيفتها لغير ها إحكاما للشهادة وضبطا للكلمة و إثباتا لغــضب الله عليها بعد أن أضمرت الحق فلم تتطق به وهي تعرفه، فاليوم لا تتكلم لا بحق

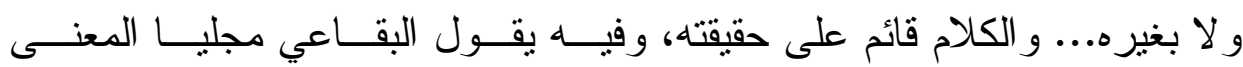

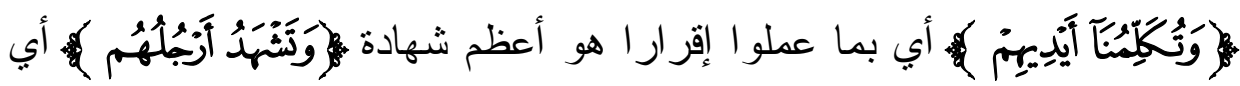

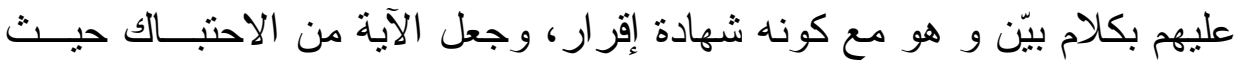

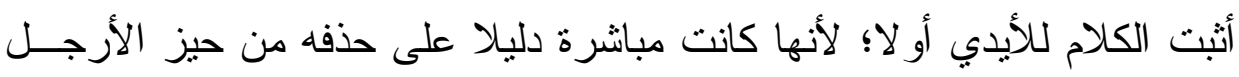

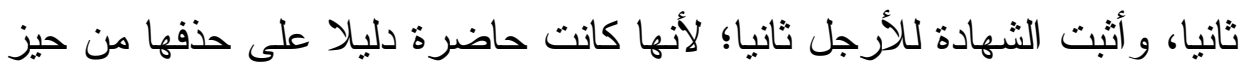
الأيدي أو لا وبقرينة أن قول المباشر إقرار وقول الحاضر شهادة('). وقد لحظ الشهاب الخفاجي ملحظا دقيقا في موضعين هنا: الأول في التوفيق

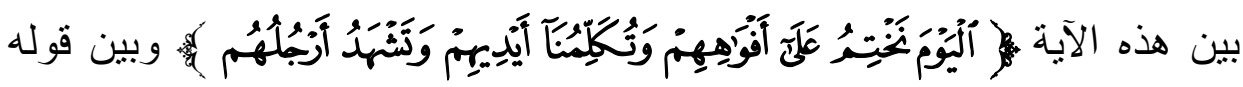

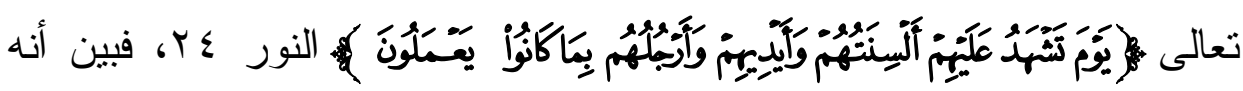
قد وفق بينهما، "بأن منهم من يعترف فتشهح عليهم الألسنة، ومنهم من ينكر لقوله

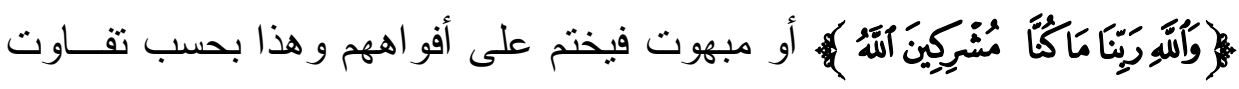

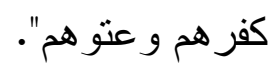
و الملحظ الثاني الذي وقف عنده الثهاب هو : "إسناد الختم إليه تعـالى دون الكلام و الثهادة، قيل لئلا يحتمل الجبر عليه، فقد علم أنه باختيار هم بعد إقدار الله

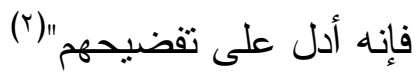

$$
\begin{aligned}
& \text { (1) ينظر السابق، Yvo/7 (Y) }
\end{aligned}
$$

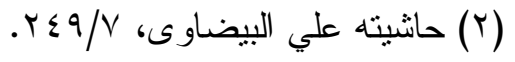


فلما كان القوم في آية يس منكرين مبهوتين مجادلين بالباطل منطيرين مسـن

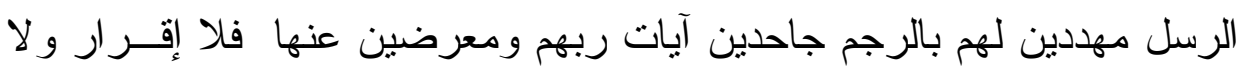
اعتر اف، ناسب ذلك الختم على الأفو اه و إثبات الكلام للأيدي، و الثهادة للأرجل،

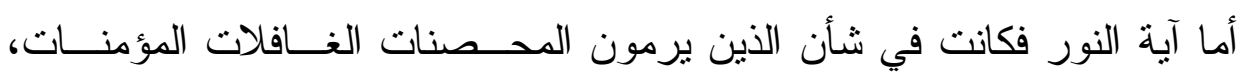

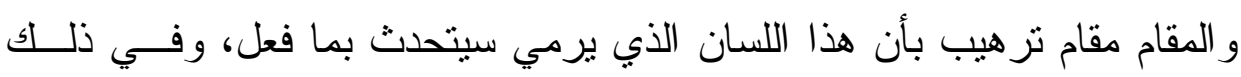

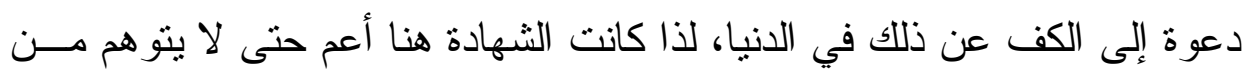

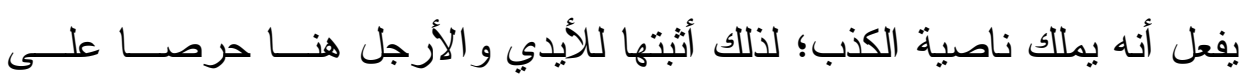
سلامة الحياة، وخاصة أن القضية مرتبطة بحديث الإفلك، فالمقام هنا فيه نوعيــة

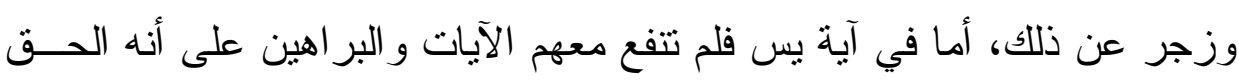

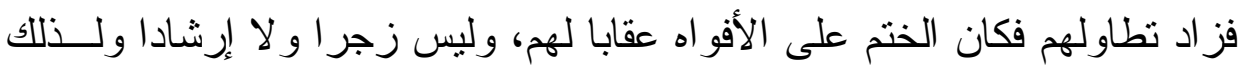
استطرد في آية يس بالطمس على الأعين فلا يرى لها أثز، بل يمسـخهم علـى

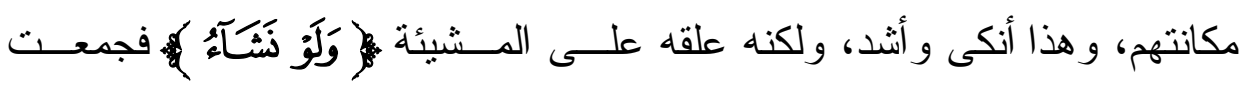

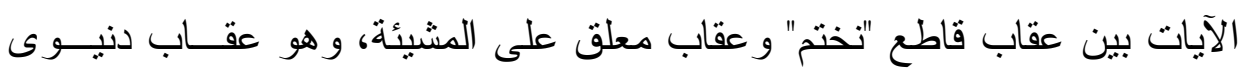
يدل على إمهال الله لهم رويدا.

ويلاحظ أن الطمس هنا جاء على الأعين وهو أثند من الغشاوة السابقة بــلـ

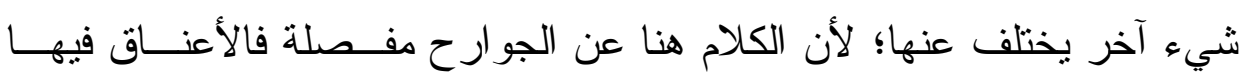

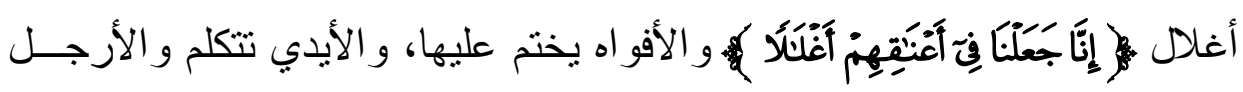
تشهد، فلكل جارحة نوع معين بخلاف عموم الطمس على الوجوه بما تحوي في

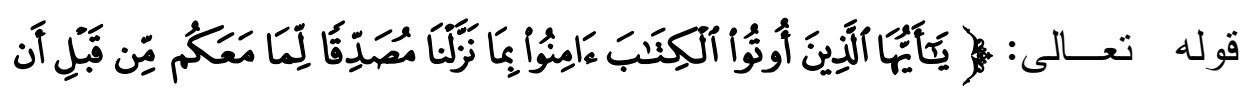

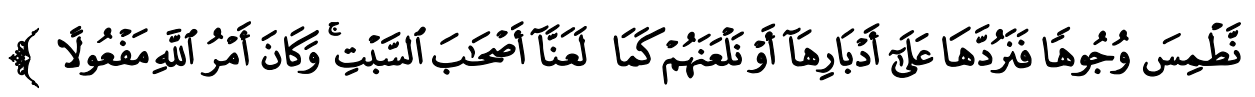
النساء 
فطمس الوجوه هنا لا يقتصر على المعنى اللغــوي المعـروف بــالمحو أو

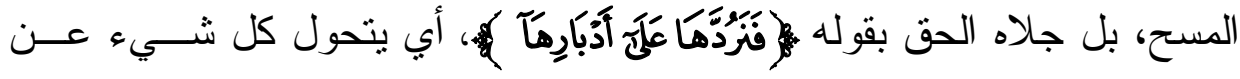

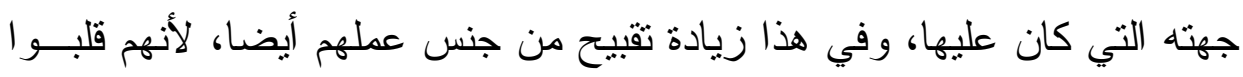

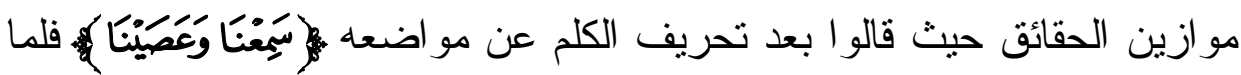
غيروا الصورة التي كان يجب أن يكونو اعليها وهي أن يقولو ا "أطعنا" غيــر الله

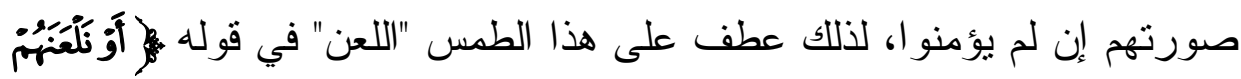

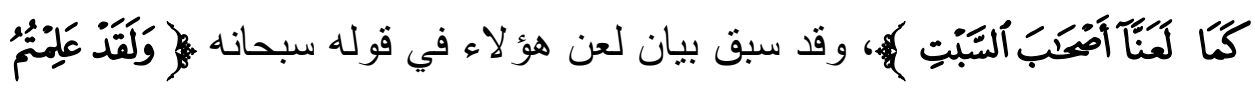

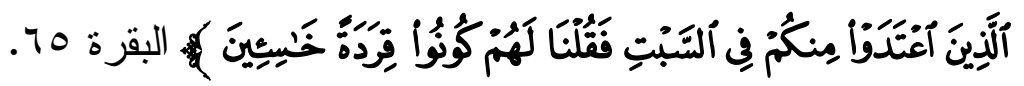
فالختم لله مقاماته التي يأتي فيها مناسبا لمو اقعه، و الطمس كذللك لله مقاماته وبذلك تتجلى فروق التعبير بما يجعل كلا مناسبا لمقامه وسياقه. 


\section{الابلحث الثالث}

\section{استعمال (طبع) على القلوب وحلدها}

جاء الطبع على القلوب فقط دون الأسماع و الأبصار أو أحدهما في عـشرة شو اهد من القرآن الكريم، توجه الإسناد إلى اسم الجلالة صريحا في ستة منهــا، و جاء التعبير بالماضي(طبع) في ثلاثة، وبالمضار ع في ثلاثة أخرى، كما جــاء

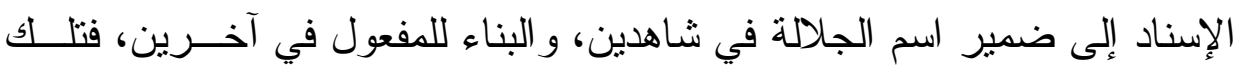
عشرة شو اهد بيانها كما يأني:

\section{أولا: شواهد التعبير بالماضي مسندا إلى اسم الجلالة:}

جاء ذللك متوجها إلى القلوب خاصة في سور : النساء، و التوبــة، ومحمــــ، ففي آية النساء يحدثنا القرآن عن أهل الكتاب الذين نقضوا الميثاق وكفروا بآيات الله وقتلو ا الأنبياء بغير حق وقاءلو اقلوبنا غلف أي خلقت هكذا، ذكر ابن عبــاس و عطاء: يعنون في أغتنية لا ذنب لنا فيها، أو أوعية للعلم نستغني بما فيها عـنـ

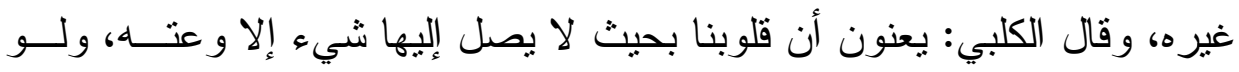
كان في حديتك شيء لو عته أيضا (').

هذا على الاختلاف في معنى (غلف) ويترجح معنى زعمهم أنها مغـشـاة لا

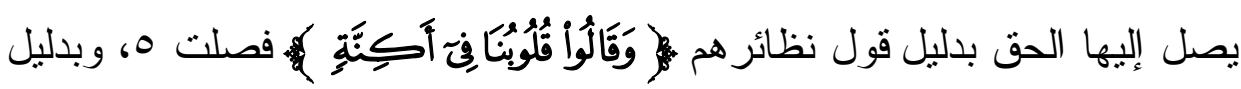

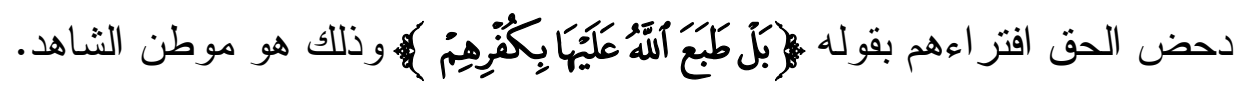

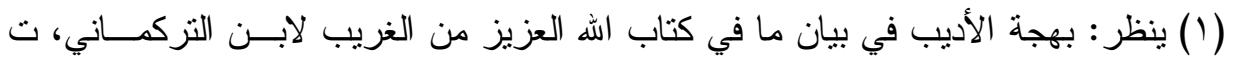

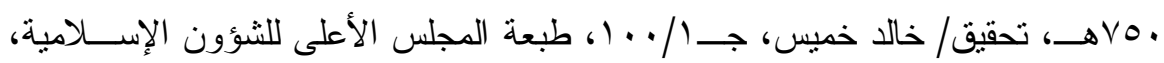

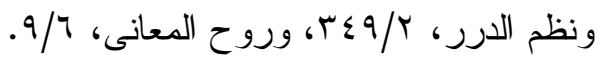




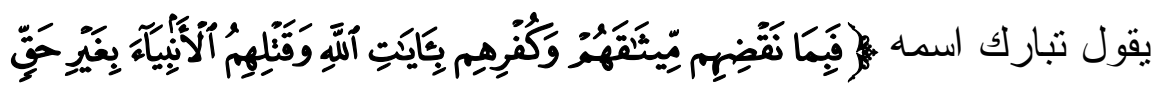

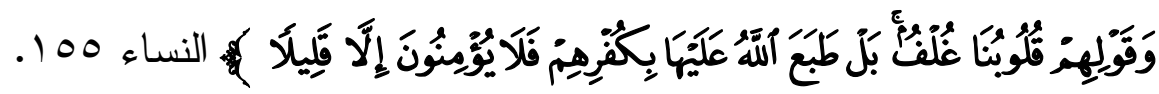

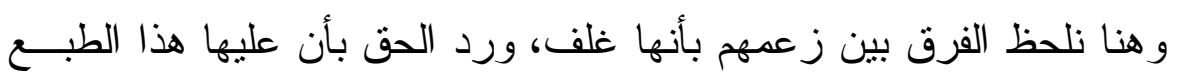
بكفر هم، و هذا يجلي أنها خلقت على الفطرة لا غشاء عليها، ولما كفروا عـاقبهم بـانه الله بذلك ووضح الزمخشري ذلك بقوله: "فقيل لهم بل خذلها الله ومنعها الألطاف بسبب كفرهم، فهم الذين غلفو ا قلوبهم بما أحدثو ا من الكفر الزائغ عن الفطـــــة

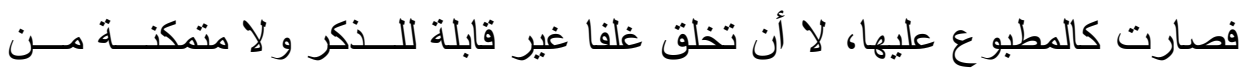
قبوله"(') فز عمهم بأنها خلقت هكذا غير مقبول وقد فعلو ا ما فعلــــوا فطبــع الله عليها بذلك، ولكنهم "قالو ا ذلك بهنا ودفعا لما قامت عليهم الحجج وظهرت لهــ

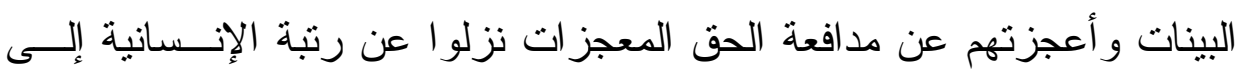
رنبة البهيمية"(')

و لا ريب أن كلام الزمخشري السابق يمثل رأي المعتزلة في أن العباد هـــ الخالقون لأفعالهم، وذللك جلي في قوله ( فهم الذين غلفو ا قلوبهم...)، ولذلك جعل الختم و الطبع مسندا إلى الله على سبيل المجاز أو التمثيل، وقد بنيت موقفي فـي هذه الدر اسة من بداية در اسة شو اهدها على عدم التأويل عملا بمذهب أهل السنة

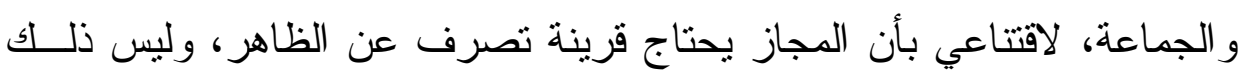
في سياق الثو اهد، فالختم و الطبع كالعزة و الإذلال كله بيد الله عقابا لمن يـستحق لـاله ذللك، وشو اهد البحث كلها تدل عليه.

$$
\begin{aligned}
& \text { (1) الكثاف، (Y) }
\end{aligned}
$$

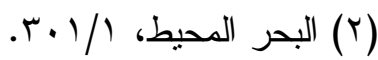




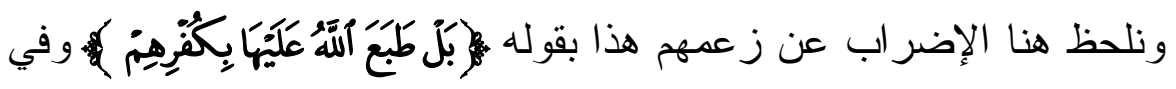

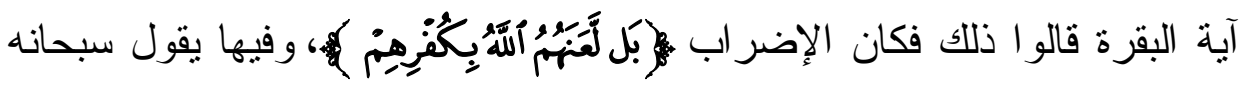

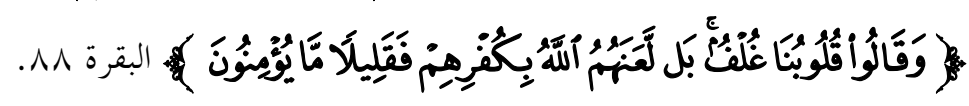

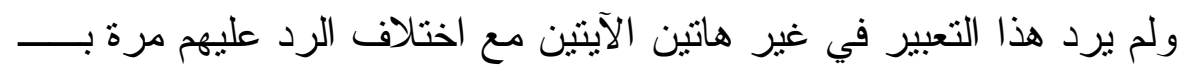

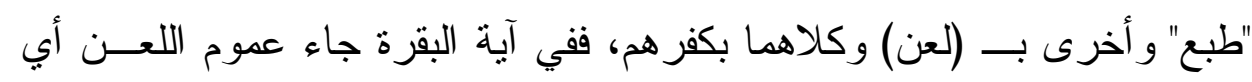

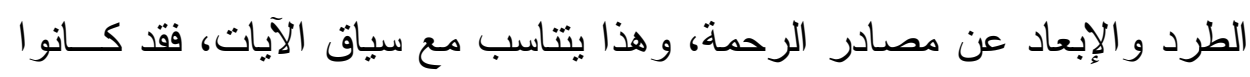

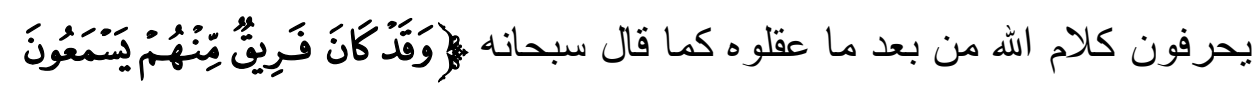

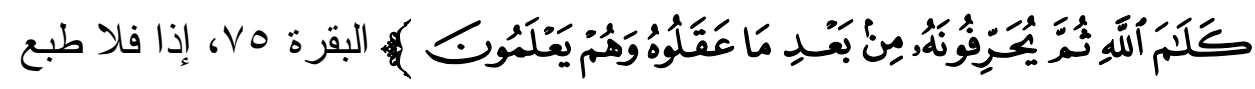
على قلوبهم، كما كانو ا يؤمنون ببعض الكتاب ويكفرون ببعض كما قــال ربنــا

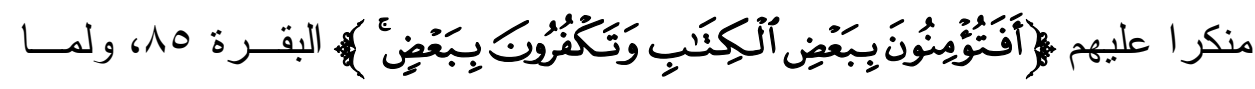

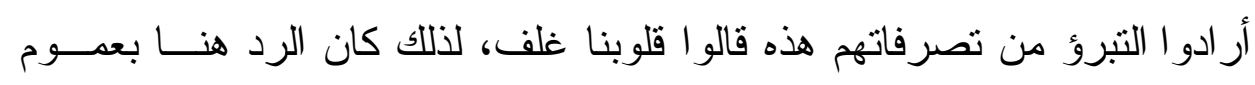

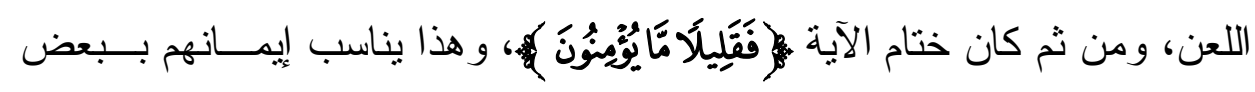

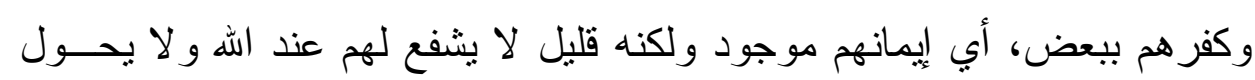
بينهم وبين اللعن.

أما الموقف في آية النساء فيتناسب معه ذكر الطبع:

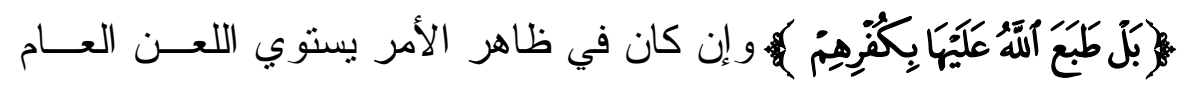

المؤدي إلى إغلاق سبل النجاة و إبعادهم عنها، و الطبع على القلوب الحائل بينهـــا

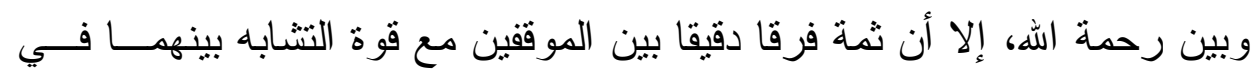

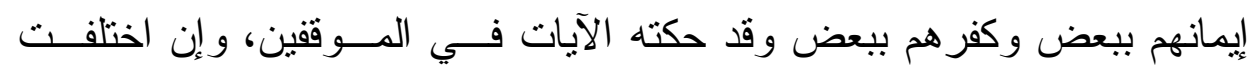
طريقة التعبير عن ذلك حيث جاء بالاستقهام الإنكارى في آية البقرة التـي فيهـا 


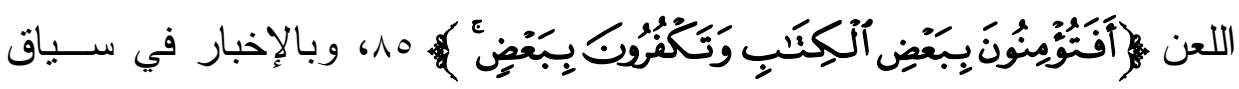

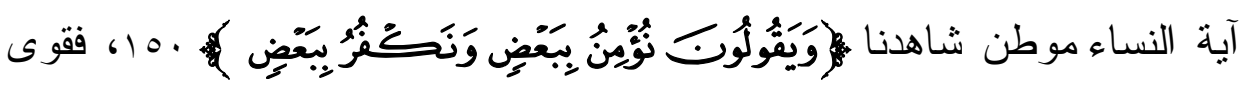

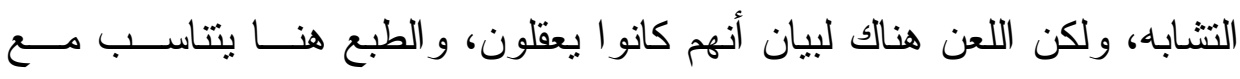

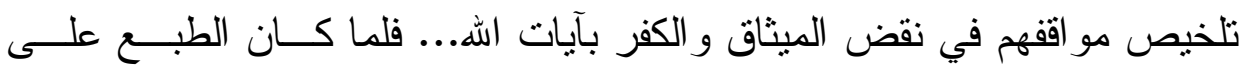

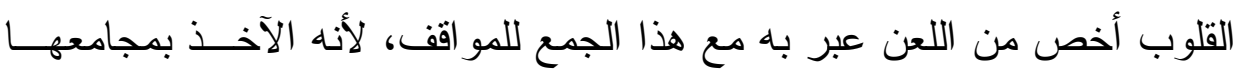

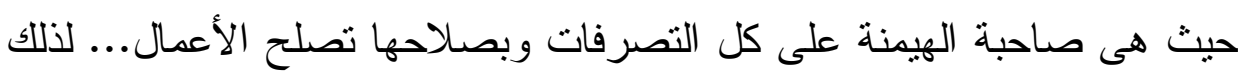

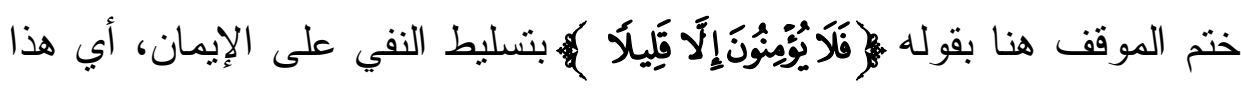

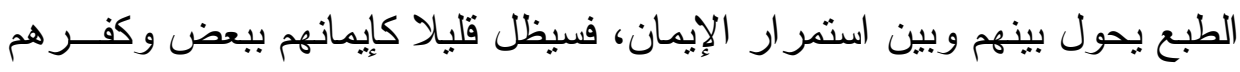

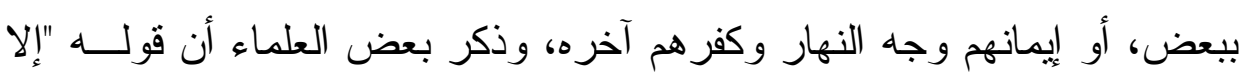

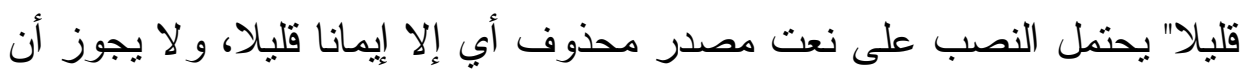

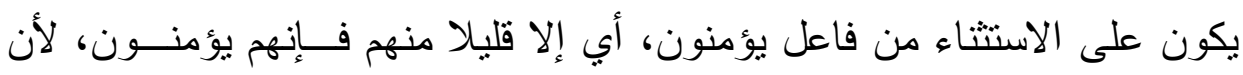

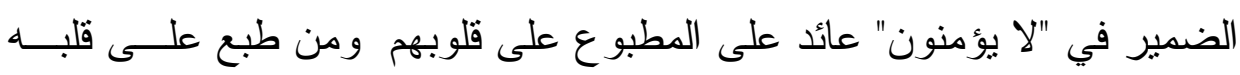

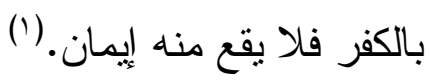
فنفي الإيمان بهذه الصورة يتتاسب مع ذكر الطبع، لأنه يمنع دخول الإيمان

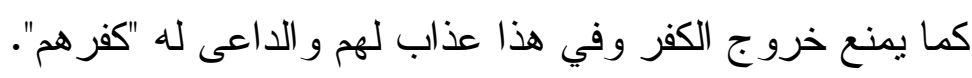

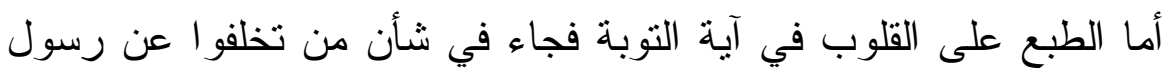

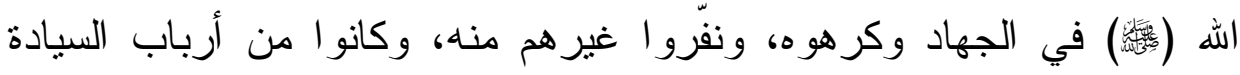

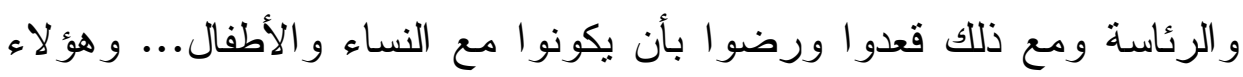

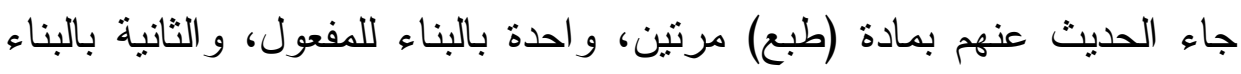

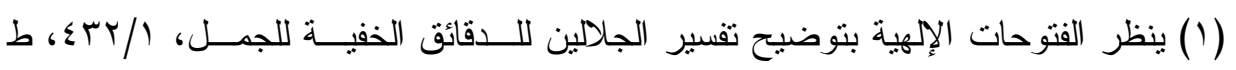
الحلبى. 
للمعلوم، و السياق يتدرج في الحديث عنهم، وييدأ بالبناء للمفعول فيقول تبارك

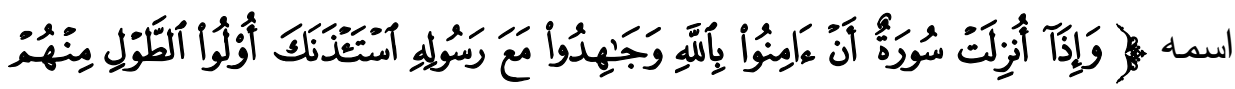

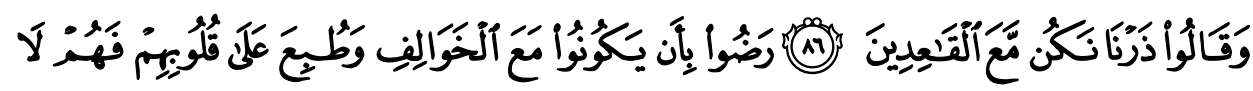

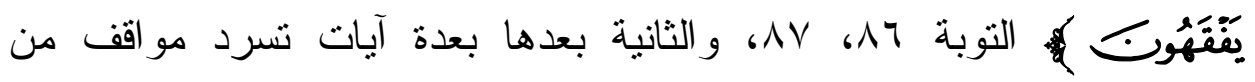

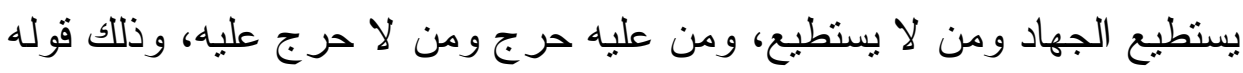

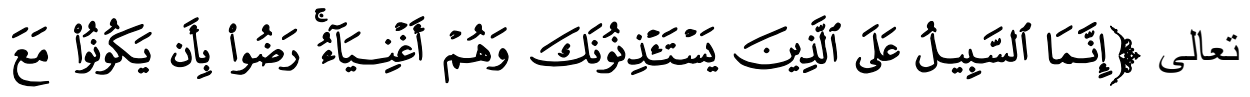

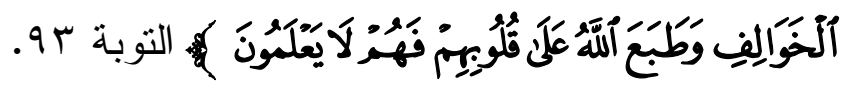

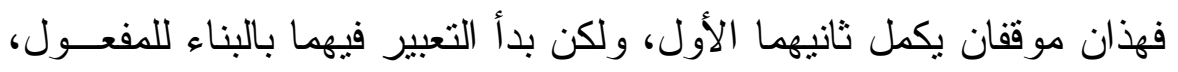

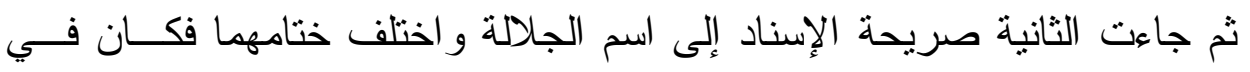

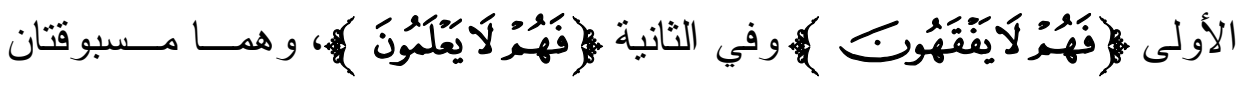

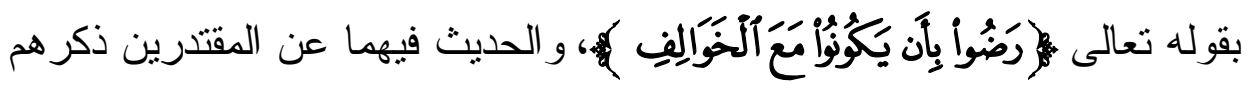

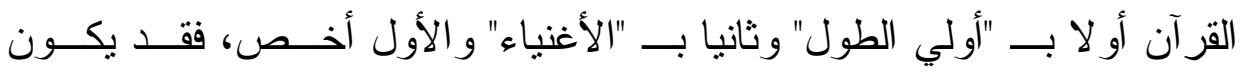

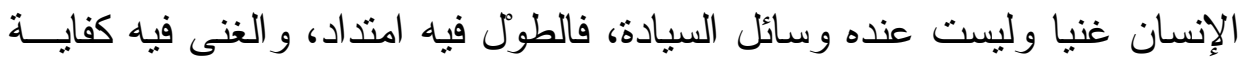

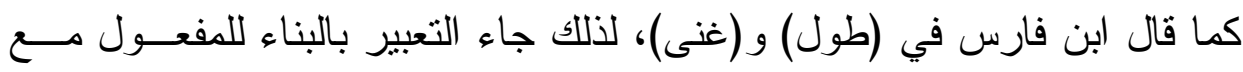

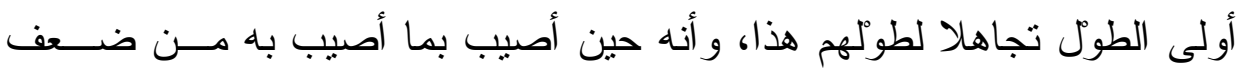

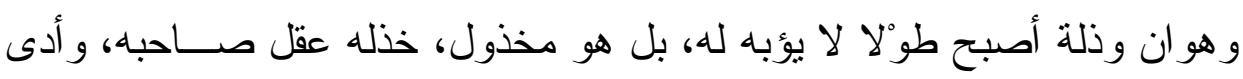
به إلى الصغار طلبا للسلامة؛ لذلك وسمه بأنهم لا يفقهون، ولما كان في الطول

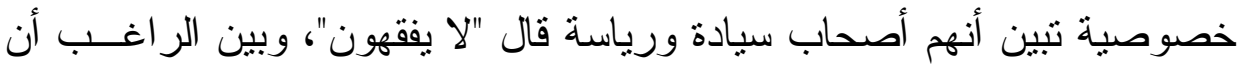

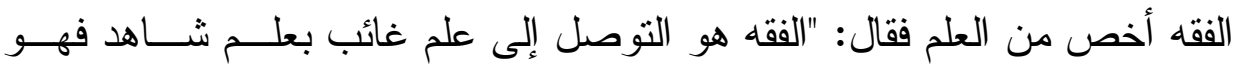

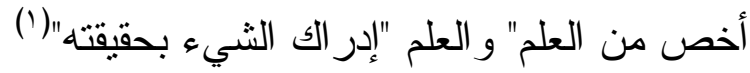

$$
\text { (1) (1) المفردات (فقه) و (علم). }
$$


ويقول أبو هلال العسكرى "الققه هو العلم بمقتضى الكلام على تأمله.." ( ) فهذا علم بفهم و إدر الك كان يتتاسب مع طوّلهم هذا لو كان طو لا ناجحا، لكن

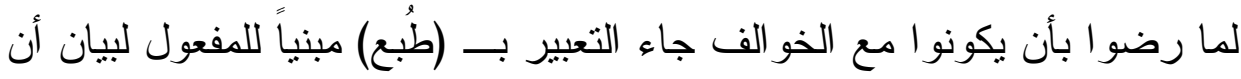
عدم إدر الك الحقائق وفقهها أدى إلى أن تكون القلوب مطبو عة على هذا الخـزـزي

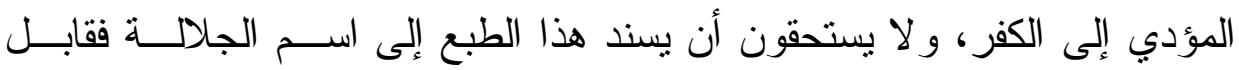

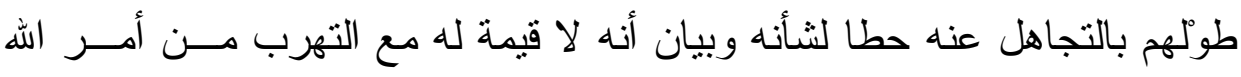
ورسوله.

أما الأغنياء فلا يشترط أن يكونو الن أولي السؤدد، بل عندهم الكفاية المادية التي بستطيعون بها حمل أنفسهم وحمل غيرهم في الوقت الذي كان فيه من عندهم الاستعداد ولكن الرسول لم يجد ما يحملهم عليه فرفع عنهم الحرج

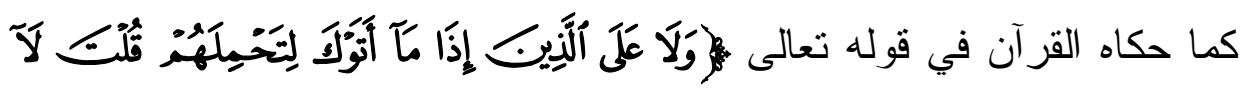

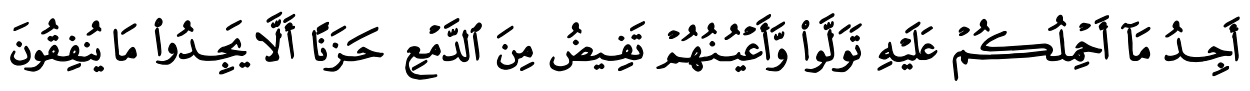
9 r 9 r

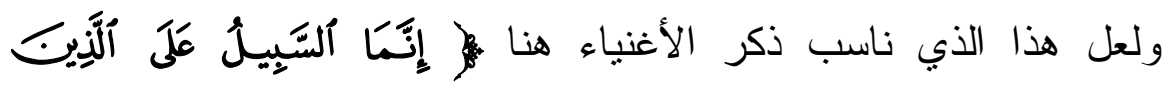

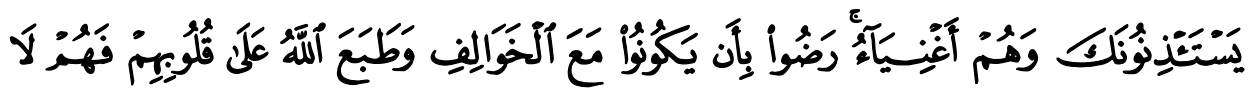

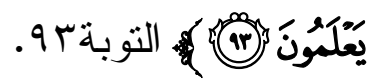
فهذا في عموم من يملك المال ويستطيع الخروج للجهاد و المـسـاعدة فيــه، ولكنه رضي - كما قال الرازى - "بالدناءة و الضعة و الانتظام في جملة الخو الف 
وطبع الله على قلوبهم فلأجل ذلك لا يعلمون ما في الجهاد مــن منـــافع الــدين

و الدنيا." (')

فهذا الطبع المسند إلى اسم الجلالة نفي عنهم العلم، وهـــا وســم بالجهـلـ بحقائق الأمور حين سلب عنهم مجرد معرفة ما لا تحتاج معرفته إلى تأمل، بعد أن انجلى الأمر وتبين شأن الجهاد.

ولما تجاهلو ا واستأذنو ا في القعود وتثاقلو ا عن حق الله ورسوله أسند الطبع

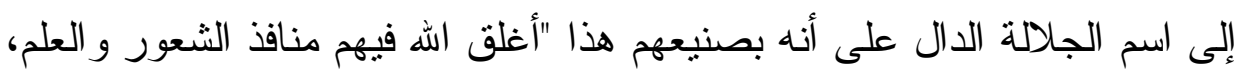

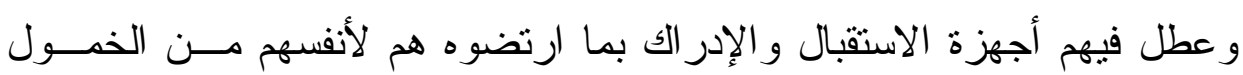

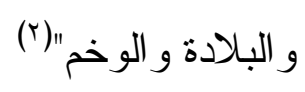

وبذلك نتاسب بناء (طبع) للمعلوم مع نفي العلم بعمومه الذي يـشـمل الفقــــ

و العلم، وهذا تدرج في إثبات جهله بحقائق الأمور حيث نفي عنهم الققه أو لا بما

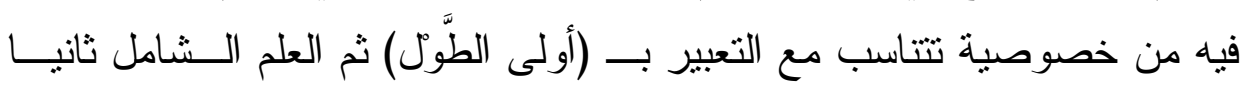
بعد ذلك بلفظ (الأغنياء) الدال على عموم الغنى سواء كان مجرد كفاية مــال أو كان مصحوبا بسؤدد، فالعام ناسب العام و الخاص ناسب الخاص، وفــي النــاني كان إسناد الطبع صريحا إلى اسم الجلالة للدلالة على عموم قدرته. وكما كان الطبع على القلوب بصيغة الماضى سبيا في سلب الفقه و العلم فقد ينجم عنه اتباع الهوى و إن صيغ السياق بو او الجمع فقد يكون أحد المجمــوعين سببا في الآخر ويكون الطبع هو الذي أدى إلى اتباع الهوى لتنبت الحجة علــيهم 


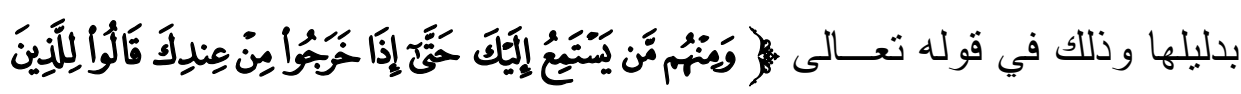

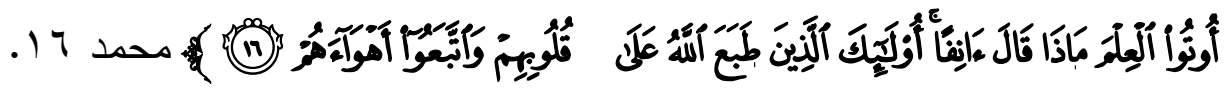
هذا حديث عن المنافقين " فقد أخرج ابن المنذر عن ابن جريح قــال: كـــان

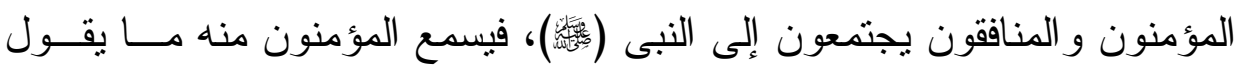

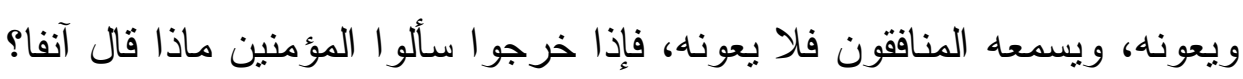

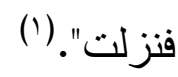

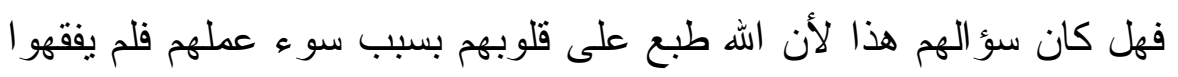

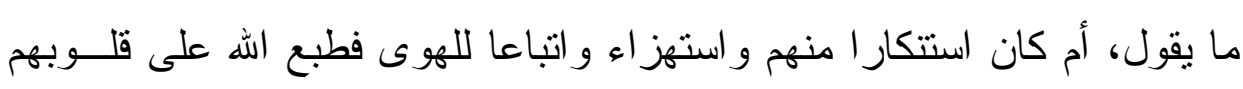
دون أن يحدد مصير هم بعد هذا الطبع إيذانا باستحقاقهم كل عذاب؟.

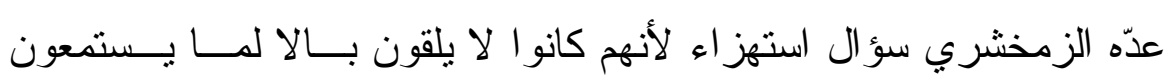

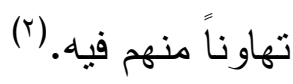

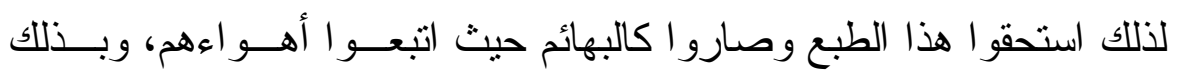

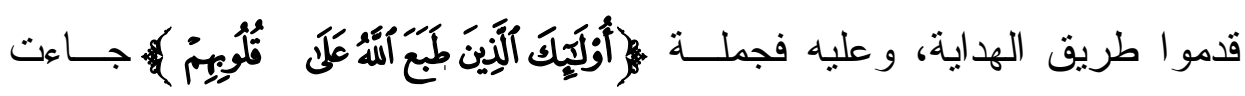
استئنافا بيانيا ينجم عن صنيعهم هذا، كأنه قيل: ما مصير من يفعل ذلك؟ فجاءت التهات

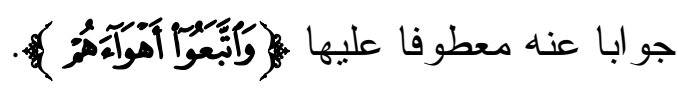

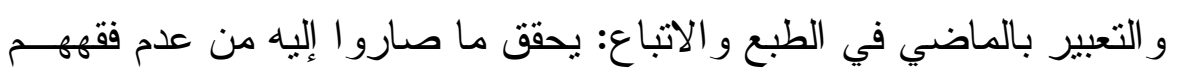

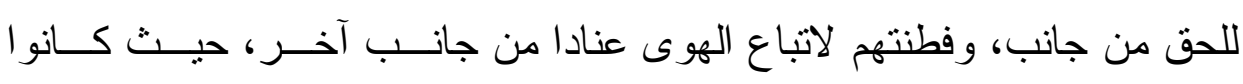

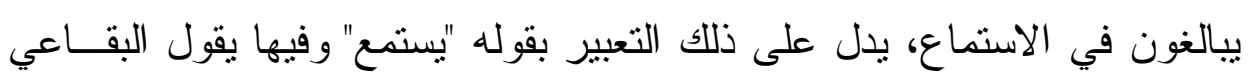

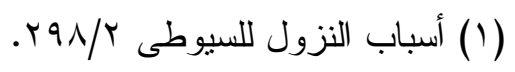

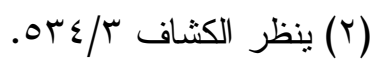


"أى بغاية جهذه لعله يجد في المتلو مطعنا يشك به على الضعفاء، وبيّن بُعـدهم

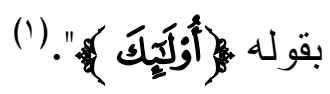

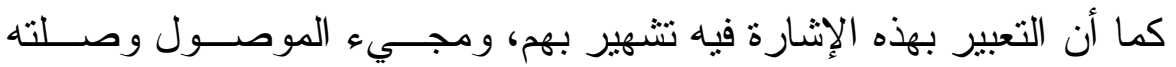
خبر ا عنها لإفادة أن هؤلاء المتميزين بهذه الصفات هم أثنخاص الفريق المتقرر بين الناس أنهم فريق مطبو ع على قلوبهم، و أنهم مُتبعون لأهو ائهم. (؟) فلما كانو ا يتظاهرون بالإسـام ويؤكدون ذلك باستماعهم مع المــؤمنين، ثــم يعودون لهذا السؤال، "ماذا قال آنفا".

أظهر الله حقيقتهم بهذا التعبير (أولئك) أى البعداء الــذين طبــع الله علــى قلوبهم فانصرفو اعن الحق، و اتبعو أهو اءهم، و الجمع بـين الطبــع والاتبـــاع يتتاسب مع مبالغتهم بالتظاهر في الاستماع المعبر عنه بلفظ يستمع. ثانيا: شواهد التعبير بالمضارع مسندا إلى صريح اسم الجلالة وإلى ضميره:

ورد ذللك بصيغة واحدة (كذللك يطبع الله) في ثلاثة شــواهد، أحــدها فـي الأعر اف، و الثاني في الروم، و الثالث في غافر . أما شاهد الأعر اف فيسبقه مباشرة شاهد جاء فيه الإسناد إلى ضمير اسم الجلالة، ثم تدرج التعبير حتى أسند الطبع إلى ظاهر اسم الجلالة، وذللك في قوله

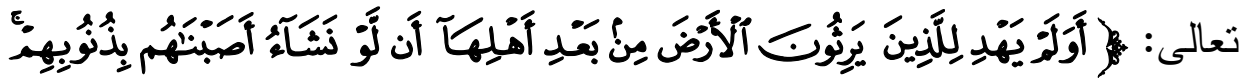

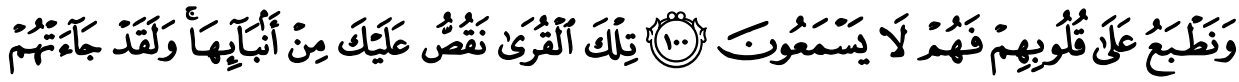

$$
\begin{aligned}
& \text { (1) نظم الدرر Ir/V } 17 \text {. }
\end{aligned}
$$

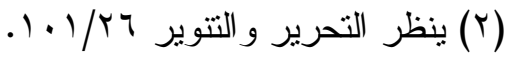




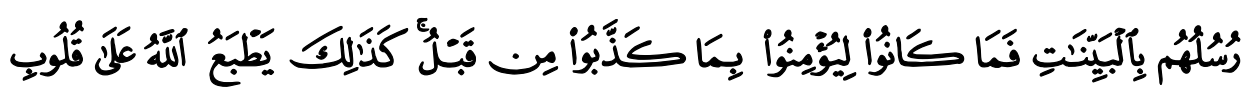

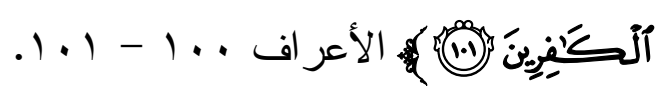

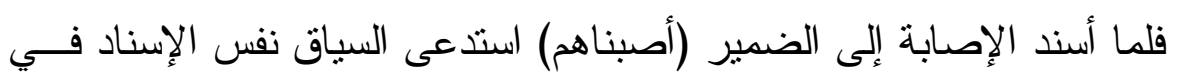

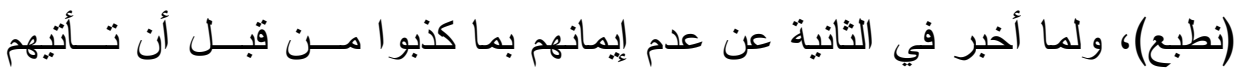

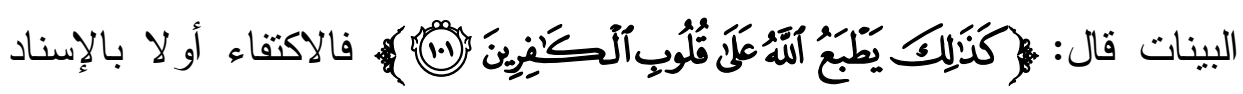

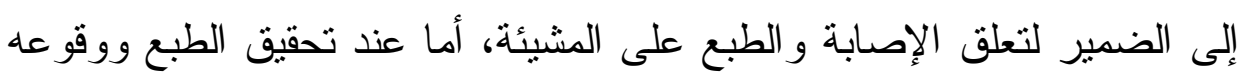

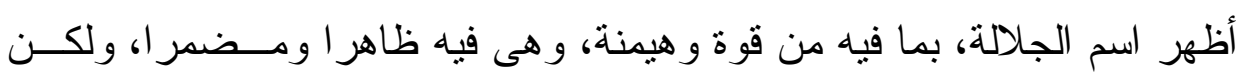
ظهور ها يتتاسب هنا مع الإصر ار على الكفر بعد مجيء البينات.

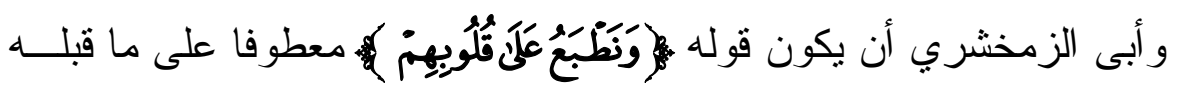

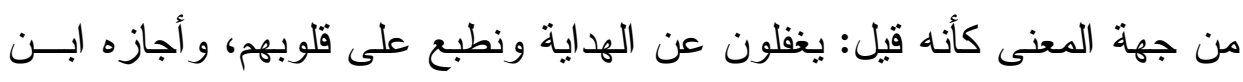

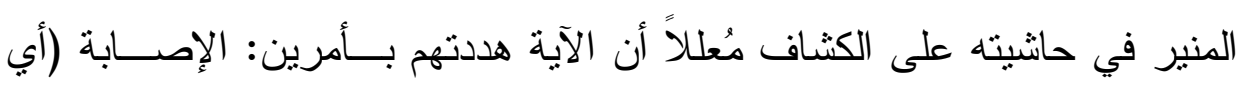

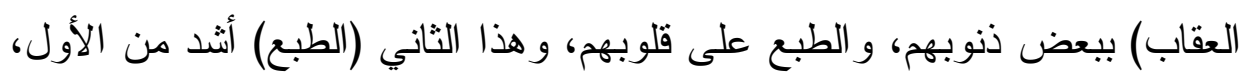

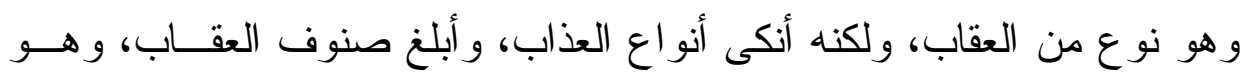

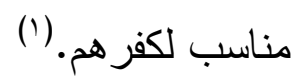

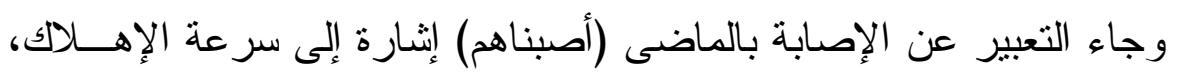

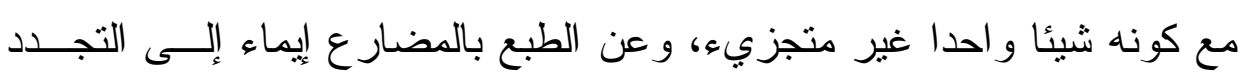

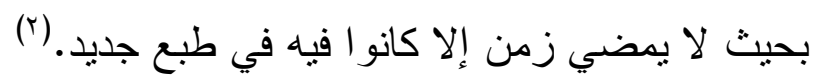

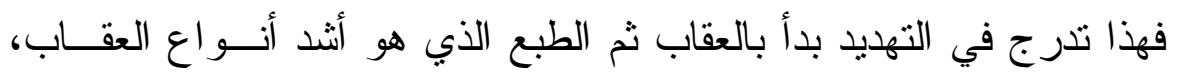

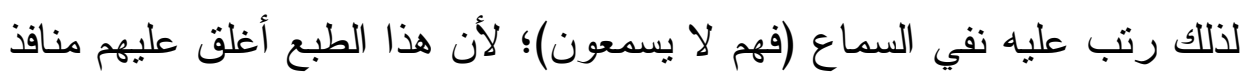

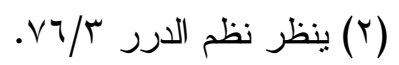


الاعتبار، وصدهم عن الدق عقابا لهم، ثم ينو اصل هذا التدرج ويخرج من طور

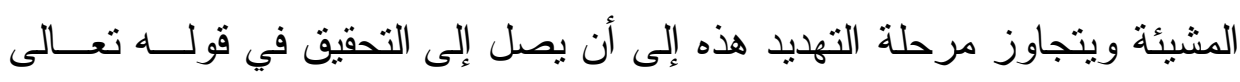

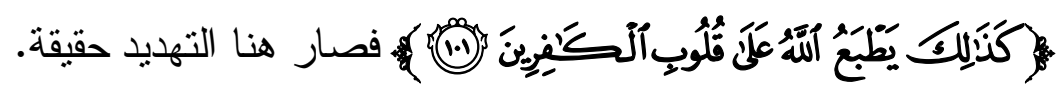
يقول الزمخشري: "أي مثل ذلك الطبع الثنديد نطبع على قلوب الكافرين"( (1)،

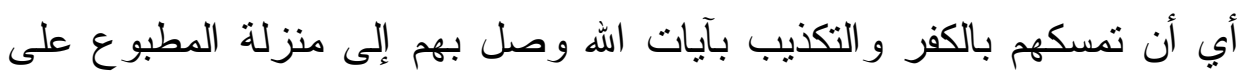

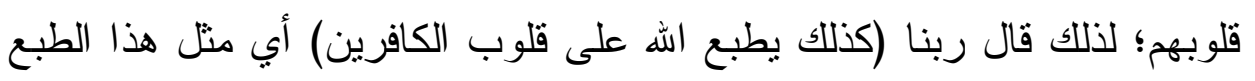

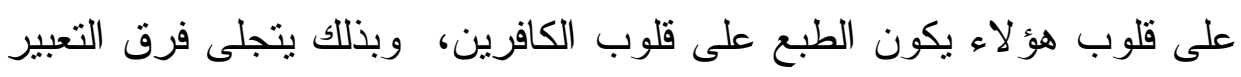

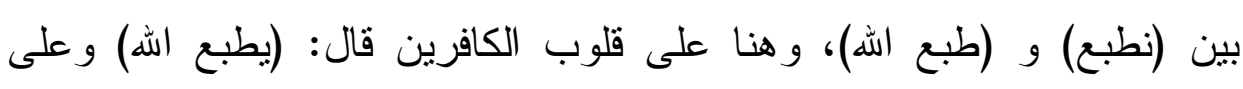

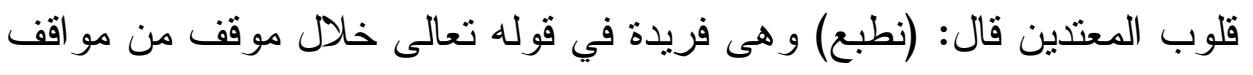

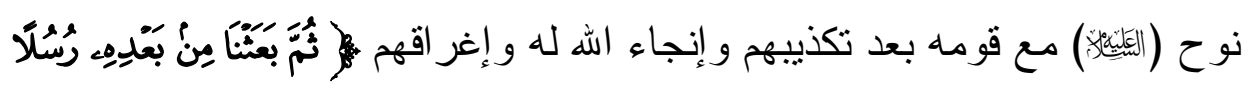

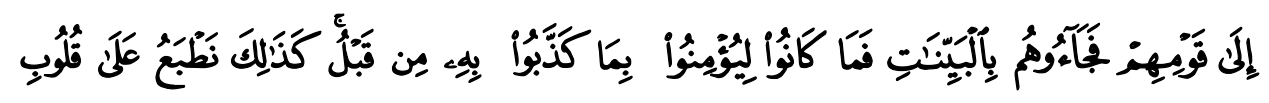

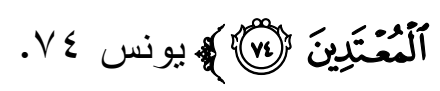

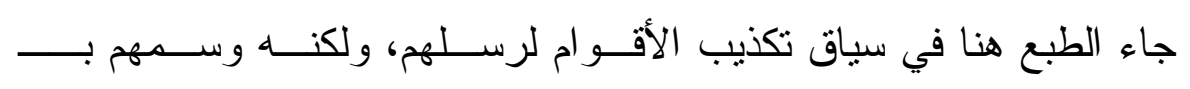

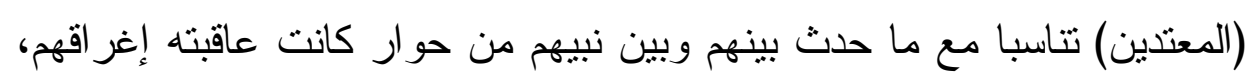

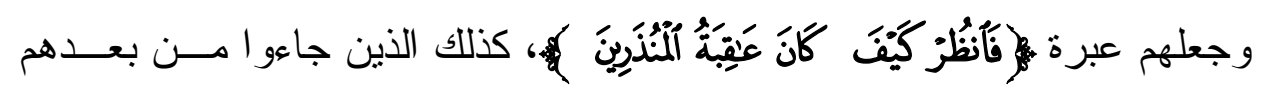

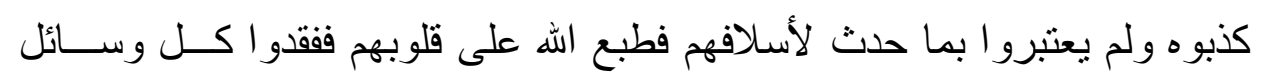

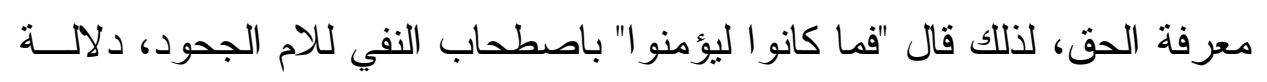

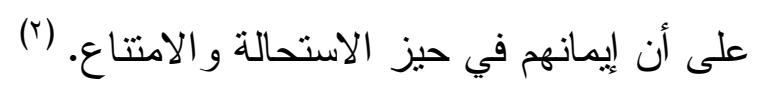

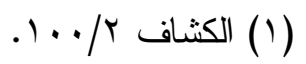

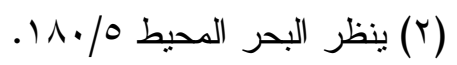


فكان الطبع في الأعر اف على قلوب الكافرين؛ لأن السياق قبلهـــا يتحـــث

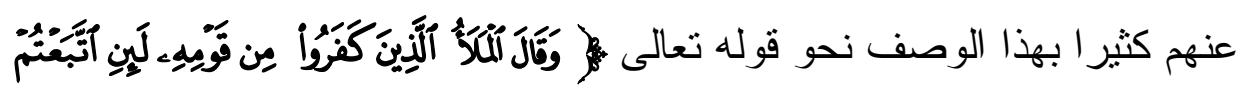

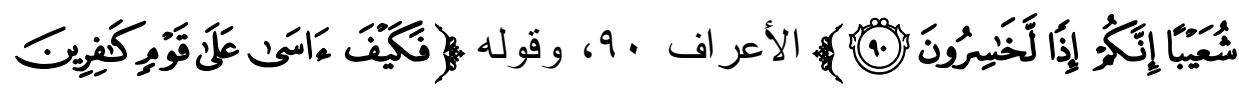

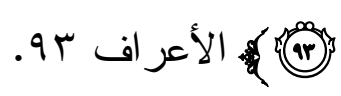

أما السياق في آية يونس فكان سياق تكذيب لذلك جعلهم معتدين لتجــاوز هم حدودهم مع أنبيائهم، وكثرة جدالهم لهم، كما كان يجادل قوم نوح نوحا ويتهمونه بذللك في قولهم

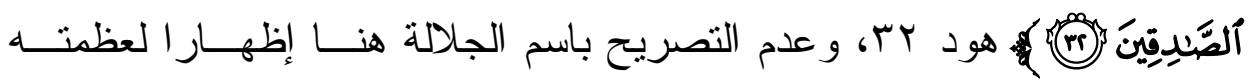

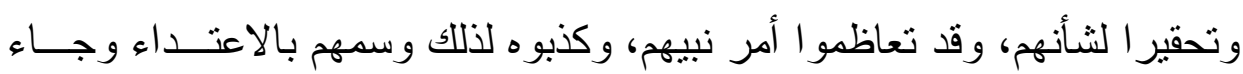
التعبير بـ (نطبع) المسند إلى ضمير العظمة حطا من تعاظمهم.

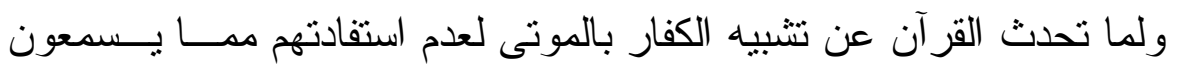

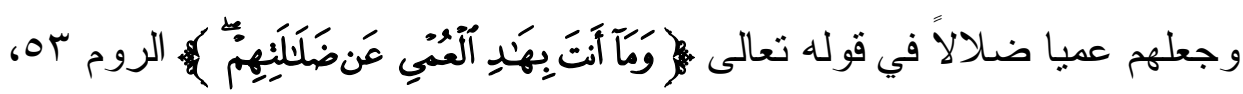

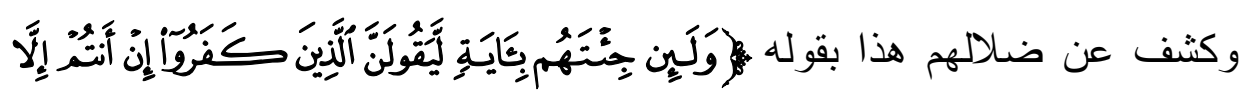

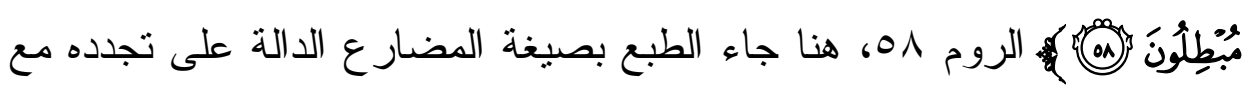

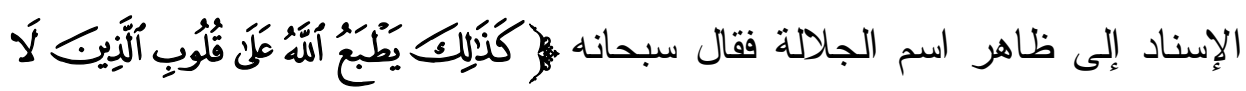

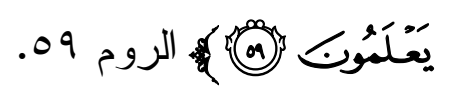

و التصريح هنا باسم الجلالة يتتاسب مع بيان دلائل قدرته في مر احل العمر

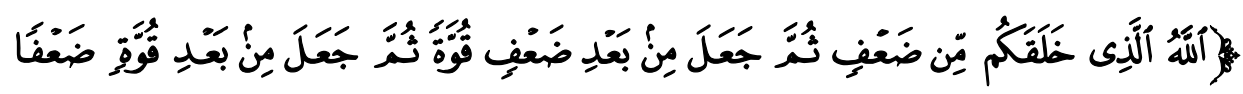

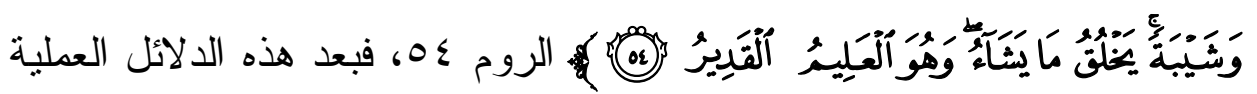

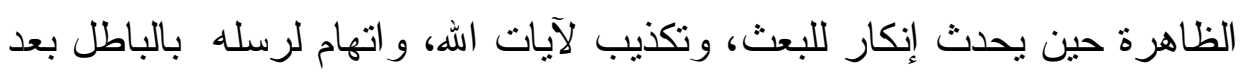


ذللك يكون الطبع على القلوب مسندا إلى ظاهر اسم الجلالة الدال على الهيمنة

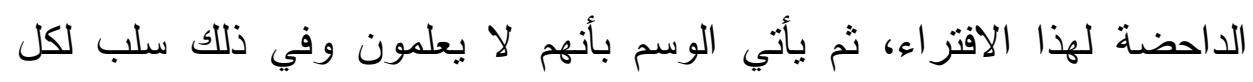

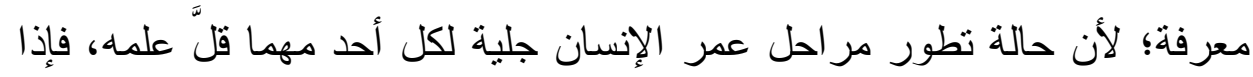

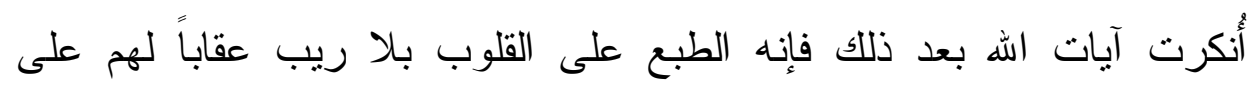

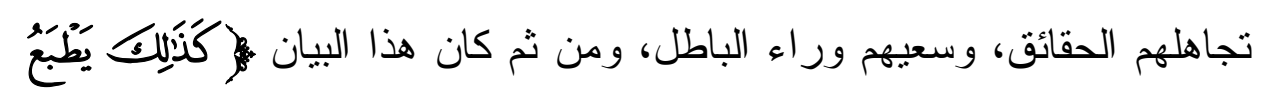

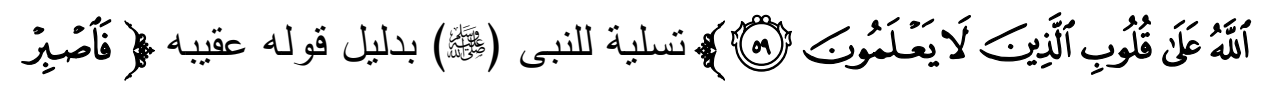

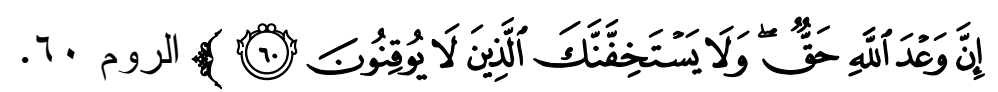
ويتبقى من شو اهد التعبير بالمضار ع التي جاء الإسناد فيها إلى ظاهر اســ

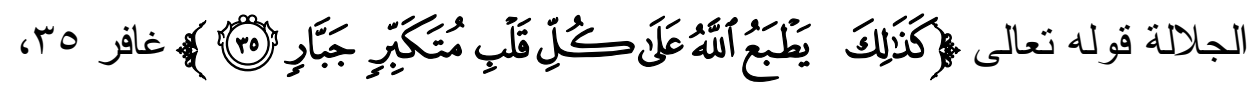
وسبقت در استها في إفر اد القلب وتتكيره في بداية هذه الدر اسة. ثالثا: التعبير بـ (طُبع) مبنيا للمفعول.

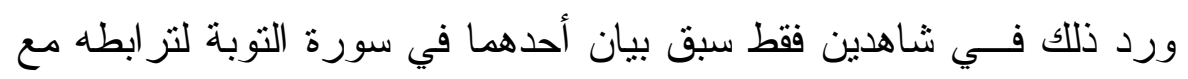

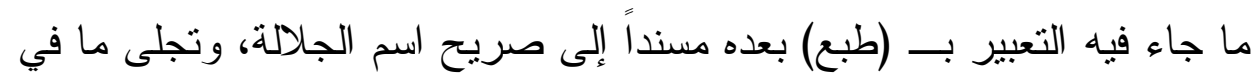

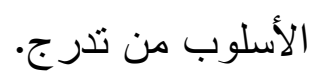

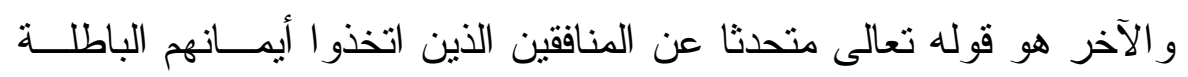

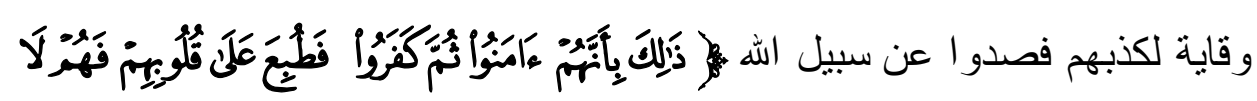

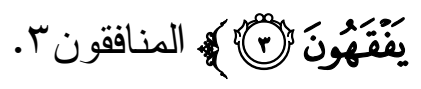
فقوله "تلك" إثنارة إلى العمل السيئ الذي جعلهم يــصدون عـن سـبيل الله

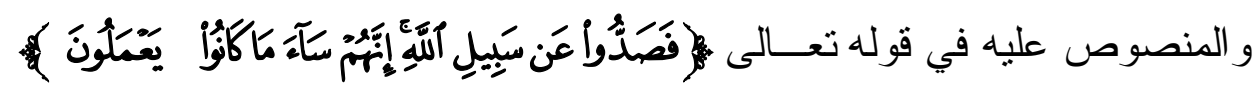

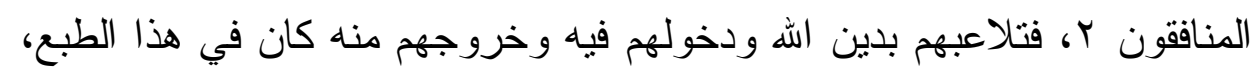

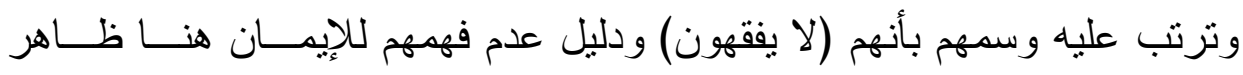


بصنيعهم هذا، فاستحقو ا هذا الطبع ليختم لهم بالكفر، و لا تكون لهم إلى الإيمـان

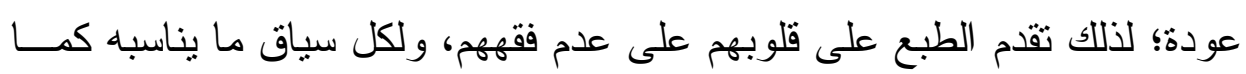
تجلى.

والش المونت للعواب 
تلك در اسة بلاغية تطبيقية موجزة تجلت من خلالها الفروق الدقيقــة بــين

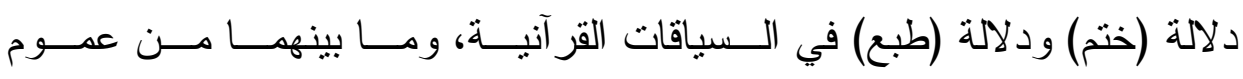
وخصوص، فمقام تستقيم فيه (ختم) دون سو اها، و آخر تو افقه (طبـعـ) و لا تقــوم

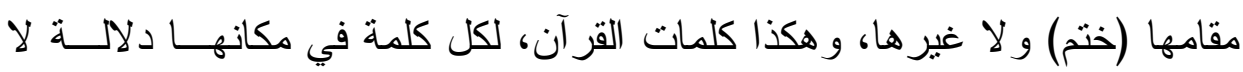
تؤديها غير ها.

وهذا البحث كله نتائج في الفروق التطبيقية بين دلالة المادتين، و اســتعمال هذه هنا وتلكك هناك، حيث حرص على الإيجاز غير المخل، ومع ذلك سأسـوق بعضا من هذه النتائج، وفي مقدمتها:

التقارب اللغوي بين دلالة المادتين جعل كثير ا من علماء اللغة لا يذكرون بينهما كبير فرق، بل فسر بعضهم ( ختم) بـــ ( طبع)ونص على أن الخـتم هــــ الطبع، و الدر اسة جلت - بايجاز - خصائص التعبير بكل منهمـــا مــن خــلال الثو اهد.

• ذكر كثير من المفسرين أنهما من باب المجاز، ور أى بعضهم صــلاحية المجاز و الحقيقة فيهما، ورجحت الحقيقة بالأدلة التي تبين أن الختم أو الطبع نوع

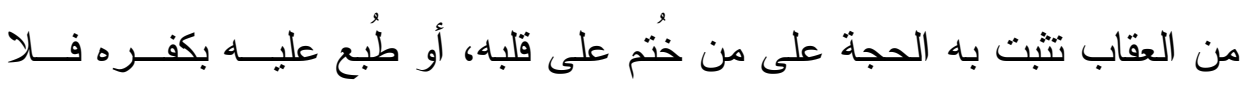
يخرج منه كفر و لا ينفذ إليه إيمان.

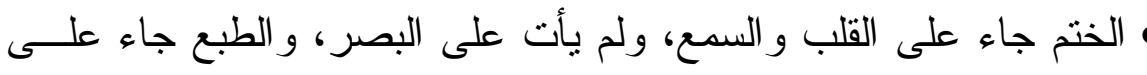

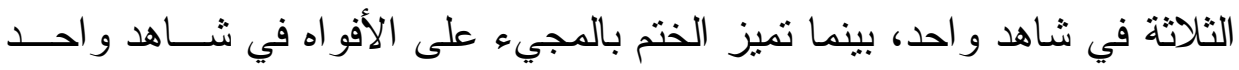
أيضا، ولكل دلالته التي بني هذا العمل على محاولة تجليتها. 
• شو اهد الطبع أكثر من ضعف شو اهد الختم، ومعظمها يختم بنفي الـسمع، أو الفقه، أو العلم، أو الإيمان، أو إثبات الغفلة، أما ختم فتارة تعطي نهاية القرار بنوع العذاب، وتارة تتدد ببعدهم عن الحق. • قد يشتركان في الحديث عن الكافرين، ولكن سياق كل منهما ينتواعم مــع ما ذكر فيه، و هذا ما قامت الار اسة عليه. 


\section{دليل المصادروالمراجع}

1 - أساس البلاغة للزمخشري.

r - أسباب النزول للسيوطي.

r- ب أسباب النزول للو احدي.

ـ - إثنار ات الإعجاز في مظان الإيجاز للنورسي تحقيق إحسان الصالحي.

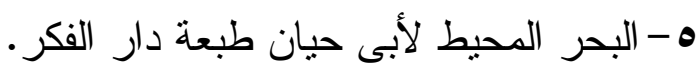

צ - التحرير و التتوير لابن عاشور ط دار سحنون.

V - الفتوحات الإلهية للجمل. دار الفكر.

1- الفروق اللغوية لأبى هلال العسكرى ط دار الإلجتب دار العلمية.

9 - الكثاف للزمخشري دار المعرفة.

• أمفردات في غريب القر آن للر اغب الأصفهاني.

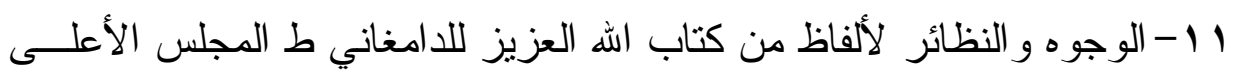

لالثؤون الإسلامية.

r ا-بهجة الأريب في بيان ما في كتاب الله العزيز من الغريب لابن التركماني ط المجلس الأعلى للشؤون الإسلامية.

r ا - تقسير الفخر الرازى ط دار الفكر.

ع أ-تهذيب اللغة للأز هري.

1 - حاثية ابن المنير الإسكندري على الكثاف.

7 ا 1 -حاثية الثهاب الخفاجي على تقسير البيضاوي.

V v روح المعانى للألوسي دار الفكر.

1 ا -في ظلال القرآن للثيخ سيد قطب دار الثروق.

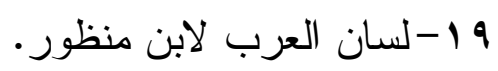

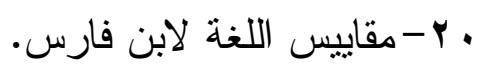

اب-نظم الدرر للبقاعي دار الكتب العلمية. 


\section{دليل الموضوعات}

\begin{tabular}{|c|c|}
\hline الصفحة & | \\
\hline 117 & 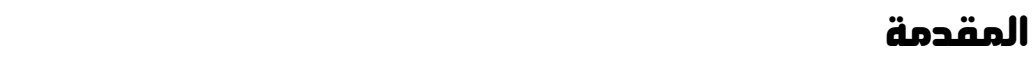 \\
\hline 111 & 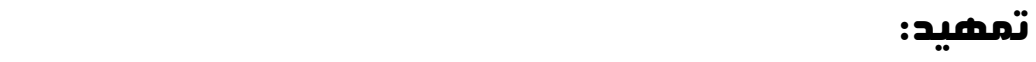 \\
\hline 111 & 1- المعانى اللغوية لمادتى (ختم و طبع). \\
\hline IrT & r- استعمال المادتين في القر آن الكريم. \\
\hline Ir & المبحث الأول: استعمال (ختم و طبع) على القلوب و الأسماع. \\
\hline IY & تحليل الشو اهد ودر اسة ما بينهما من فروق ومناقثة أقو ال العلماء. \\
\hline Ira & المبحث الثانى : استعمال (خــتم) علــى القلـــوب و اختــــــــاصا \\
\hline Ira & الختم على القلوب ومقاماته. \\
\hline $1 \leq \varepsilon$ & الختم على الأفو اهو ومعناه. \\
\hline $1 \leq \Lambda$ & المبحث الثالث: استعمال (طبع) على القلوب وحدها. \\
\hline $1 \leq \Lambda$ & أولا: شو اهد التعبير بالماضى مسندا إلى اسم الجلالة. \\
\hline $1 \leqslant 9$ & تحليل الثو اهد ومناقشتها. \\
\hline
\end{tabular}




\begin{tabular}{|c|c|}
\hline 107 & و إلى ضانيـا: شو اهد التعبير بالمضار ع مسندا إلى صريح اســـم الجلالـــة \\
\hline 17. & ثالثا: التعبير بـ (طبع) مبنيا للمفعول. \\
\hline $17 r$ & الخاتمـة. \\
\hline $17 \varepsilon$ & دليل المصادر والمراجع. \\
\hline 170 & دليل الموضوعات. \\
\hline
\end{tabular}

